
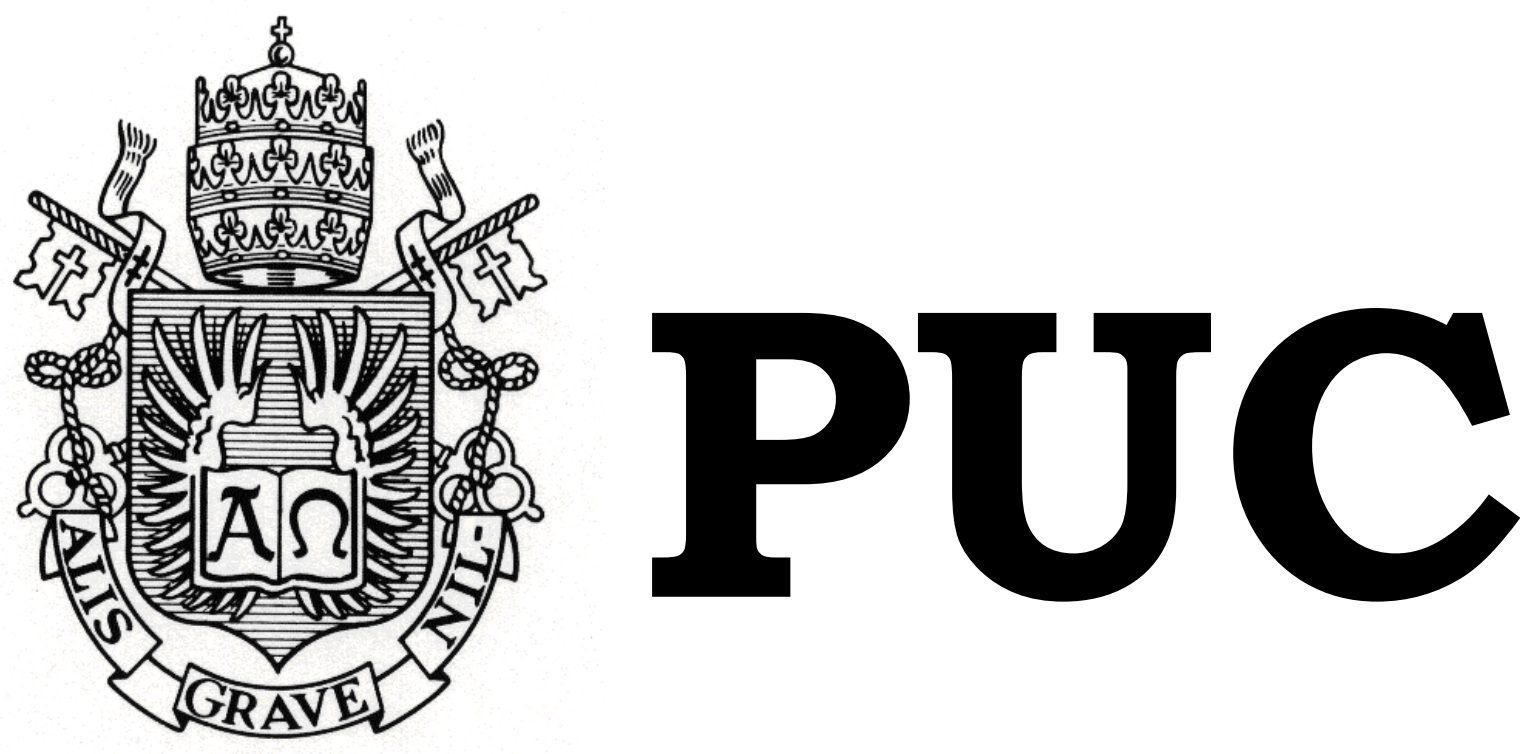

DEPARTAMENTO DE DIREITO

A Construção Democrática do Sentido da Constituição: entre soberania popular e jurisdição constitucional por

Pedro Henrique Chaves de Azevedo Beff de Araujo

ORIENTADOR: Adriano Pilatti

2015.2

PONTIFÍCIA UNIVERSIDADE CATÓLICA DO RIO DE JANEIRO

RUA MARQUÊS DE SÃO VICENTE, 225 - CEP 22453-900

RIO DE JANEIRO - BRASIL 


\title{
A Construção Democrática do Sentido da Constituição: entre soberania popular e jurisdição constitucional
}

\author{
por \\ Pedro Henrique Chaves de Azevedo Beff de \\ Araujo
}

Monografia apresentada ao Departamento de Direito da Pontificia Universidade Católica do Rio de Janeiro (PUC-Rio) para a obtenção do Título de Bacharel em Direito.

Orientador(a): Adriano Pilatti 
"Eu acredito é na rapaziada

Que segue em frente e segura o rojão

Eu ponho fé é na fé da moçada

Que não foge da fera, enfrenta o leão

Eu vou à luta com essa juventude

Que não corre da raia a troco de nada

Eu vou no bloco dessa mocidade

Que não tá na saudade e constrói

A manhã desejada"

(Gonzaguinha, "E vamos à luta”) 


\section{Agradecimentos}

À minha família, em especial minha mãe Ana Cecilia, cujo suporte e apoio foram fundamentais para a realização deste trabalho na densidade desejada.

Ao professor Adriano Pilatti, pela valiosa orientação, pelas pertinentes sugestões e conhecimentos transmitidos, sem os quais o presente trabalho ficaria aquém do potencial do tema proposto.

À Clarice, pela paciência e companheirismo ao longo desta minha trajetória acadêmica na graduação de Direito, figura determinante para que eu tivesse chegado até este momento.

À Camila, amiga sempre solidária, e à minha irmã Ana Carolina, igualmente pela paciência e amparo no auxílio com os retoques finais desta monografia.

A todos vocês, minha gratidão. 


\section{Resumo}

O presente trabalho tem por escopo a análise das interações entre Direito e Democracia no contexto das sociedades contemporâneas complexas, marcadas sobretudo pela característica do pluralismo. Para tanto, partindo-se da premissa de que somente uma democracia de cunho participativa pode atender aos anseios sociais da pós-modernidade, o objeto de estudo focalizou nas construções teóricas que conferiam destaque ao exercício da soberania popular para além dos sistemas puramente representativos, como é o caso, por exemplo, do modelo deliberativoprocedimental de Jürgen Habermas. Não obstante, reconhecendo-se o relevante papel da jurisdição constitucional no plano sensível da garantia dos direitos fundamentais, pressupostos essenciais para o próprio cumprimento das regras do jogo democrático, cabe analisar a legitimidade da atuação das Cortes Constitucionais - e, no caso brasileiro, do Supremo Tribunal Federal -, bem como sua função contramajoritária de proteção das minorias no âmbito do constitucionalismo democrático. Neste ínterim, surge com especial valor a contribuição de Peter Häberle ao apresentar uma tese pluralista da interpretação constitucional mediante uma "sociedade aberta de intérpretes da Constituição", que pretende desmonopolizar a atividade hermenêutica constitucional dos juízes e tribunais ao ampliar e pluralizar o círculo de participantes na construção do sentido da Constituição. Tem-se, portanto, uma democratização da interpretação constitucional.

\section{Palavras-chave}

Soberania popular; pluralismo; democracia participativa; jurisdição constitucional; sociedade aberta de intérpretes da Constituição. 


\section{Abstract}

This study aims to analyze the interactions between Law and Democracy in the context of complex modern societies, shaped especially by the pluralism. To this end, starting from the premise that only a participatory nature of democracy can meet the social aspirations of post-modernity, the object of study focused on the theoretical constructs that gave prominence to the exercise of popular sovereignty beyond the purely representative systems, as it is the case, for example, of Jürgen Habermas' deliberative-procedural model. Nevertheless, recognizing the important role of constitutional jurisdiction in the sensible plan of guarantee of fundamental rights - which are essential prerequisites for the proper compliance with the rules of the democratic game - we need to analyze the legitimacy of the activities of the Constitutional Courts - and, in Brazil, the Supreme Court - as well as its "countermajoritarian" acting of protection of minorities within the framework of democratic constitutionalism. In the meantime, Peter Häberle's contribution comes with special value in presenting a pluralist theory of constitutional interpretation by an "open society of interpreters of the Constitution", which aims to demonopolise the constitutional hermeneutic activity of judges and courts as the circle of participants in the construction of the meaning of the Constitution is extended and pluralized. Therefore there is a democratic constitutional interpretation.

\section{Keywords}

Popular sovereignty; pluralism; participatory democracy; constitutional jurisdiction; public company of interpreters of the Constitution. 


\section{Sumário}

Introdução

Capítulo 1. Da Soberania Popular ........................................................... 9

1.1. Considerações sobre o Poder Constituinte ...................................... 9

1.2. O conceito de povo na perspectiva de Friedrich Müller ......................16

1.3. A soberania popular no modelo deliberativo-procedimental de democracia de Jürgen Habermas .........................................................23

1.4. A Constituição de 1988 e a democracia participativa ..........................31

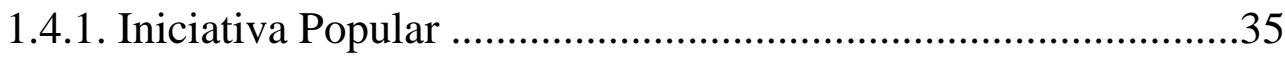

1.4.2. Plebiscito e Referendo Popular ...............................................36

1.4.3. Ação Popular ...................................................................36

1.4.4. Participação Popular não institucionalizada .............................37

Capítulo 2. Da Jurisdição Constitucional ...............................................41

2.1. A Força Normativa da Constituição ...................................................41

2.2. O guardião da Constituição e a doutrina de Hans Kelsen ....................46

2.3. A legitimidade democrática da jurisdição constitucional e o papel do Supremo Tribunal Federal no desenho institucional brasileiro ...................54

Capítulo 3. Da Construção Democrática do Sentido da Constituição ........63

3.1. A Sociedade Aberta dos Intérpretes da Constituição: a contribuição de Peter Häberle para a interpretação pluralista da Constituição .63

3.2. A influência de Häberle no contexto jurídico brasileiro: Leis 9.868/99 e $9.882 / 99$ .71

Conclusão .77

Bibliografia .81 


\section{INTRODUÇÃO}

Considerando o atual estágio de protagonismo institucional que a jurisdição passou a assumir no cenário político, muito em decorrência das novas configurações que ensejaram o Estado democrático de direito, porém, sobretudo em razão da relevância do papel do que se chamou de constitucionalismo democrático no âmbito das sociedades contemporâneas, nota-se que a relação Direito-Democracia hoje traduz duas faces de uma mesma moeda. A posição de centralidade que a Constituição ocupa no ordenamento jurídico traz consigo outro fenômeno como consequência lógica do sistema: a ascensão daqueles órgãos que foram incumbidos juridicamente de resguardá-la. Esta função é conferida, hegemonicamente, à atividade jurisdicional e, em última instância, às Supremas Cortes ou Tribunais Constitucionais, autorizadas a dar a palavra final acerca da interpretação da Constituição.

Não obstante, as sociedades contemporâneas possuem como características principais justamente a sua complexidade e a sua pluralidade. Este arranjo social, heterogêneo na sua essência, reclama também novos arranjos democráticos, capaz de abarcar as hodiernas expectativas de cidadania de participação popular na vida pública. Isto é evidenciado pela sistemática crise de representatividade fruto do predominante modelo político vigente. A soberania popular de uma sociedade tipicamente pluralista não pode ser manifestada genuinamente somente de maneira mediada, cabendo, portanto, a observância de novos instrumentos que atendam o dinamismo social através de uma democracia verdadeiramente participativa.

Neste ínterim, a Constituição de 1988 instituiu, sistematicamente, mecanismos para integrar a sociedade perante os poderes públicos em diversas esferas de atuação e participação também nos mais variados processos de tomada de decisão. Sendo assim, além de conferir legitimidade democrática à atividade estatal, estes mecanismos de realização também 
podem ser identificados, a partir de um novo senso comum jurídico trazido pela lógica constitucional, pela compreensão do direito como instrumento de transformação social politicamente legitimado ${ }^{1}$. Neste sentido, diante da própria perspectiva constitucional, que reconhece o pluralismo como pilar de sua própria interpretação e da construção de seu próprio significado ante a potência democrática, questiona-se a concentração da atividade hermenêutica constitucional à cega tecnicidade de uma comunidade estritamente jurídica, em especial à atuação jurisdicional. Sobre essa questão Boaventura de Sousa Santos realiza

[...] uma crítica ao monopólio estatal e científico do direito. Esta premissa exige que sejam desveladas as alternativas do dogmatismo jurídico e à teoria positivista do direito apostando numa concepção forte de pluralismo jurídico e numa concepção política do direito. A concepção de um direito plural que está presente de diferentes formas em diferentes espaços de sociabilidade e que neles pode assumir o papel contraditório de ser simultaneamente fonte de poder, diferenciação e exclusão e de luta contra o poder $[\ldots]^{2}$

Nesta linha, a orientação procedimental do direito deve obedecer aos preceitos de democratização e participação pluralista, tanto na sua interpretação quanto na sua aplicação, já que ele próprio possui papel fundamental na construção da democracia. Assim, a jurisdição constitucional necessita de uma abertura participativa para a construção plural e democrática do sentido da Constituição, algo que pode ser alcançado mediante a tese da sociedade aberta dos intérpretes da Constituição de Peter Häberle.

\footnotetext{
${ }^{1}$ SANTOS, Boaventura de Sousa. Para uma Revolução Democrática da Justiça. $3^{\mathrm{a}}$ ed. São Paulo: Cortez, 2011, p. 15.

${ }^{2}$ Ibid. p. 14.
} 


\section{CAPÍTULO 1}

\section{DA SOBERANIA POPULAR}

\subsection{Considerações sobre o Poder Constituinte}

É comumente afirmado na doutrina clássica da teoria do direito a visão oriunda da perspectiva kelseniana de que toda norma jurídica retira seu fundamento de validade da norma que lhe seja hierarquicamente superior. Desta forma, é intuitivo concluir, num ordenamento jurídico como o nosso em que vigora a tese da supremacia da Constituição, que todas as outras normas infraconstitucionais retiram seu fundamento de validade do texto da Constituição. Contudo, essa construção teórica visa tão somente a conceber uma estrutura coerente e que garanta a unidade do sistema jurídico já posto - ou seja, já estabelecido -, que tem como seu ápice justamente a Constituição. Esta, por sua vez, não retira seu fundamento de validade de nenhuma norma jurídica hierarquicamente superior ${ }^{3}$, já que que ela mesma é a norma suprema do ordenamento jurídico. Não obstante a obviedade deste raciocínio, apresenta-se quase que imediatamente a questão: de onde então a Constituição retira sua validade e legitimidade?

A autoridade máxima da Constituição, segundo Paulo Gustavo Gonet Branco, vem de uma força política capaz de estabelecer e manter o vigor normativo do Texto $^{4}$. Essa força política é conhecida como Poder Constituinte, assim denominado, em linhas gerais, por consistir em um poder efetivo, que através da "manifestação de vontade de quem o exerce e o consentimento ou a sujeição de quem a ele se submete, tem a capacidade de

\footnotetext{
${ }^{3}$ MENDES, Gilmar Ferreira; BRANCO, Paulo Gustavo Gonet. Curso de Direito Constitucional. $7^{\mathrm{a}}$ ed. São Paulo: Saraiva, 2012, p. 73.

${ }^{4}$ Salienta ainda este autor que ao "contrário do que ocorre com as normas infraconstitucionais, a Constituição não retira o seu fundamento de validade de um diploma jurídico que lhe seja superior, mas se firma pela vontade das forças determinantes da sociedade, que a precede”, ibid., p. 117.
} 
elaborar uma Constituição e de determinar sua observância" ${ }^{5}$. Neste sentido, a Constituição é produto do Poder Constituinte originário, que gera e organiza os poderes do Estado, também denominados poderes constituídos. Sob este aspecto, mostra-se válida a crítica de Antonio Negri a respeito do conceito jurídico tradicional do Poder Constituinte:

\begin{abstract}
"[...] o poder constituinte não tem sido considerado apenas a fonte onipotente $\mathrm{e}$ expansiva que produz as normas constitucionais de todos os ordenamentos jurídicos, mas também sujeito dessa produção, uma atividade igualmente onipotente e expansiva. Desse ponto de vista, o poder constituinte tende a se identificar com o próprio conceito de política, no sentido com que esse é compreendido em uma sociedade democrática. Portanto, qualificar constitucional e juridicamente o poder constituinte não será simplesmente produzir normas constitucionais e estruturar poderes constituídos, mas sobretudo ordenar o poder constituinte enquanto sujeito, regular a política democrática"6
\end{abstract}

Feita esta breve e genérica explanação, cabem algumas considerações acerca da teoria referente ao Poder Constituinte. A doutrina constitucionalista é pacífica ao atribuir, historicamente, a Emmanuel Joseph Sieyès a autoria da primeira teorização do poder constituinte - e que inclusive cunhou o termo , através do opúsculo clássico Qu'est-ce que le Tiers État?, escrito ainda no curso do processo revolucionário francês. ${ }^{7}$

Como se sabe, o contexto social pré-revolucionário na França era turbulento e Sieyès buscou formular um manifesto contra a estrutura política do Antigo Regime que vigorava no final do século $\mathrm{XVIII}^{8}$, ilustrado pelo sistema de composição do parlamento francês. O Primeiro e o Segundo Estados correspondiam respectivamente ao clero e à nobreza, ou seja, à aristocracia, enquanto o Terceiro Estado era a representação do restante da população e,

\footnotetext{
${ }^{5}$ BARROSO, Luís Roberto. Curso de Direito Constitucional Contemporâneo. $5^{\text {a }}$ ed. São Paulo: Saraiva, 2015, p. 138, asseverando ainda que "dificilmente será possível falar na vigência de uma Constituição onde haja desobediência generalizada".

${ }^{6} \mathrm{E}$ completa, ao aludir sobre a própria característica do poder constituinte em resistir à constitucionalização: "A coisa se torna ainda mais difícil porque a democracia também resiste à constitucionalização: de fato, a democracia é teoria do governo absoluto, ao passo que o constitucionalismo é teoria do governo limitado e, portanto, prática da limitação da democracia". NEGRI, Antonio. $O$ Poder Constituinte: ensaio sobre as alternativas da modernidade. Trad. Adriano Pilatti. $2^{a}$ ed. Rio de Janeiro: Lamparina, 2015, p. 1.

${ }^{7}$ SILVA, José Afonso da. Poder Constituinte e Poder Popular: estudos sobre a Constituição. $1^{\mathrm{a}}$ ed. São Paulo: Malheiros, 2002, p. 84.

${ }^{8}$ GUIMARAENS, Francisco de. O Poder Constituinte na Perspectiva de Antonio Negri: um conceito muito além da modernidade hegemônica. Rio de Janeiro. 2002. 187 p. Dissertação (Mestrado em Direito) - Departamento de Direito da PUC-Rio, p. 109.
} 
em que pese este último traduzir-se na esmagadora maioria do povo francês, o sistema não permitia que seus interesses políticos prevalecessem ao contrariar os interesses dos outros dois estamentos. Assim, a obra de Sieyès deflagra a própria dinâmica da Revolução ao constatar a sub-representação do Terceiro Estado, vinculando-o à ideia de Nação, apresentando suas reivindicações e, finalmente, elaborando a distinção essencial entre poder constituinte e poder constituído ${ }^{9}$. Neste ínterim, ao associar o Terceiro Estado ao conceito de "nação" e assentar sobre ela os pressupostos de Soberania e Onipotência, Sieyès rompe com a legitimidade monárquica do poder. Se a nação é soberana, ela tem poder para conduzir o seu próprio destino é e capaz de estabelecer, do nada, e através de uma decisão originária, um novo ordenamento jurídico não vinculado ao Direito preexistente ${ }^{10}$. Esse é o conceito básico de Poder Constituinte originário, sendo ele inicial, ilimitado e incondicionado, ao passo que os poderes constituídos seriam limitados justamente por decorrerem dele.

Note-se que, apesar da relevância e influência de ROUSSEAU para o amadurecimento do pensamento revolucionário francês e mesmo para o estabelecimento das novas bases políticas após este evento, BARROSO explica por que Sieyès assenta sua tese da soberania sobre a ideia de Nação e não de povo $^{11}$, como aludia o clássico pensador iluminista:

"Para dar viabilidade prática à teoria e legitimar a Assembleia Nacional como poder constituinte, Sieyès afastou-se da doutrina rousseauniana da 'vontade geral' e da necessidade de participação direta de cada indivíduo, substituindo-a pelo conceito de 'representação política'. A soberania popular rousseauniana foi substituída pela ideia de "soberania nacional'."12

\footnotetext{
${ }^{9}$ BARROSO, Luís Roberto. Op. Cit., p. 131.

${ }^{10}$ MENDES, Gilmar Ferreira; BRANCO, Paulo Gustavo Gonet. Op. Cit., p. 118.

${ }^{11}$ Sobre isso, Rousseau, no Capítulo II do Livro II de seu O Contrato Social, diz: “A vontade ou é geral ou não existe; ou é a vontade do corpo do povo, ou somente de uma parte. No primeiro caso, essa vontade declarada é um ato de soberania e constitui lei; no segundo, não é senão uma vontade particular ou um ato de magistratura; quando muito é um decreto".

12 BARROSO, Luís Roberto. Op. Cit., p. 132. Nesta linha, José Afonso da Silva ressalta que é "extraordinário que, sendo basicamente afirmativa da concepção revolucionária da soberania do povo, construída por Rousseau, acabou possibilitando o desenvolvimento da teoria da soberania nacional, de corte conservador. Ora, Sieyès usa o conceito de Nação não no sentido sociológico, mas como equivalente ao Terceiro Estado, ou seja, como conjunto dos indivíduos que pertencem à ordem comum", Poder Constituinte e Poder Popular, op. cit., p. 83.
} 
O problema de se conferir a soberania à concepção abstrata e vazia de Nação desconsiderando os interesses difusos - porém concretos - do povo, unicamente para se legitimar o assentamento da teoria da supremacia constitucional através de uma Constituição elaborada por meio de uma assembleia constituinte, implica, na prática, subordinar e submeter o Poder Constituinte aos mecanismos do sistema representativo ${ }^{13}$. Ao problematizar a questão, NEGRI ressalta as vicissitudes e contradições de se reduzir à representação política um poder essencialmente ilimitado e originário:

\begin{abstract}
"Desse modo, o poder constituinte é absorvido pela máquina da representação. O caráter ilimitado da expressão constituinte é limitado na sua gênese, porquanto submetido às regras e à extensão relativa do sufrágio; no seu funcionamento, porquanto submetido às regras parlamentares; no seu período de vigência, que se mantém funcionalmente delimitado, mais próximo à forma da ditadura clássica do que à teoria e às práticas da democracia: em suma, a ideia de poder constituinte é juridicamente pré-formada quando se pretendia que ela formasse o direito, é absorvida pela ideia de representação política quando se almeja que ela legitimasse tal conceito. Assim, o poder constituinte, enquanto elemento conexo à representação (e incapaz de exprimir-se senão por meio da representação), é inserido no grande quadro da divisão social do trabalho. Era desse modo, pois, que a teoria jurídica do poder constituinte procurava resolver o presumido círculo vicioso que caracterizaria a essência do poder constituinte. Mas o que significa encerrar o poder constituinte na representação, quando esta última não é mais que uma engrenagem da máquina social da divisão do trabalho? O que significa isso senão a negação da própria realidade do poder constituinte, sua fixação em um sistema estático, a restauração da soberania tradicional contra a inovação democrática?"14
\end{abstract}

Diante disso, ao se invocar a soberania nacional como titular do Poder Constituinte e combiná-lo inerentemente ao modelo representativo, Sieyès admitiu que a Constituição fosse elaborada não diretamente pelo povo, mas por uma assembleia constituinte, composta por representantes eleitos que, em tese, expressava a vontade da nação. Sendo assim, não havia a exigência ideológica de que a Constituição elaborada pelo órgão representativo fosse submetida à ratificação popular ${ }^{15}$. Em ROUSSEAU, pelo contrário, é possível perceber evidente valorização ao que seria uma atual noção de democracia deliberativa em detrimento do modelo puramente representativo, desenvolvendo certos conceitos dentro da sua teoria do Pacto Social. Para

\footnotetext{
${ }^{13}$ GUIMARAENS, Francisco de. Op. Cit., p. 111.

${ }^{14}$ NEGRI, Antonio. Op. Cit., p. 3-4.

${ }^{15}$ BARROSO, Luís Roberto. Op. Cit., p. 142.
} 
ele, o Soberano é o povo e a vontade geral pode ser interpretada abstratamente como o elemento essencial para a manifestação do Poder Constituinte fundado na soberania popular ${ }^{16}$. O conceito de "vontade geral" em ROUSSEAU seria, portanto, uma espécie de interesse comum como resultado do exercício da consciência racional coletiva de todos os cidadãos que integram o corpo social. Neste passo, no Capítulo III do Livro II de $O$ Contrato Social, há a distinção essencial da "vontade geral" e da "vontade de todos", sendo esta última hipótese somente o conjunto de interesses particulares. Assim, a concordância de todos os interesses particulares se forma por oposição ao de cada um; em contraposição, a vontade geral visa tão somente ao interesse comum da coletividade:

"Com frequência, há muita diferença entre a vontade de todos e a vontade geral; esta
considera apenas o bem comum, enquanto a outra prende-se ao interesse privado,
não sendo senão uma soma de vontades particulares: porém, se retirarmos dessas
mesmas vontades os mais e os menos que se destroem mutuamente, resta como soma
das diferenças a vontade geral" "17 Contudo, tal construção teórica não passou sem críticas. Apesar da tentativa de ROUSSEAU de consagrar o povo como o titular absoluto da soberania, o conceito vago e abstrato de vontade geral não dava instrumentos e mecanismos concretos de como essa soberania seria exercida na práxis política. Diante disso, NEGRI expõe o que seria o paradoxo de Rousseau, ou seja, "o paradoxo de um pensamento que nutre uma concepção imediata e radical do poder constituinte na exata medida em que afirma, ao mesmo tempo, a onipotência de um poder soberano abstrato" ${ }^{18}$. Este enigma teórico a respeito do fundamento abstrato da vontade geral acabou, por fim, dando

\footnotetext{
${ }^{16}$ No Capítulo VII do Livro I do $O$ Contrato Social, Rousseau observa que "a deliberação pública, que pode obrigar todos os súditos para com o Soberano, por causa das duas relações sob as quais cada um deles é considerado, não pode, pela razão contrária, obrigar o Soberano para consigo mesmo e que, portanto, é contra a natureza do corpo político que o Soberano se imponha uma lei que não possa infringir [...]donde se percebe que não há nem pode haver nenhuma espécie de lei fundamental obrigatória para o corpo do povo, nem mesmo o contrato social."

${ }^{17}$ Ibid. p. 45.

${ }^{18}$ NEGRI, Antonio. Op. Cit., p. 214. E continua ainda no mesmo parágrafo: "como pode um pensamento abstrato e generalizador, uma hipóstase metafísica (como é a vontade geral) ser apropriada e tão radicalmente transformada por uma prática política de massa que pretende instaurar, social e politicamente, uma igualdade real?".
} 
ensejo à tese revolucionária de Sieyès de que, ainda que fosse reconhecida a titularidade da soberania ao povo, esta deveria ser exercida por uma classe apta a representar os interesses de toda a nação.

É interessante notar que, mesmo atualmente, quando a ideia de soberania popular e o reconhecimento da titularidade do Poder Constituinte ao povo é hegemônico e predominante, ainda permanece prevalente a noção do seu exercício pela via indireta, ou seja, por meio de representantes eleitos. Isto pode ser verificável mesmo no Preâmbulo ${ }^{19}$ da atual Constituição de 1988 que, não obstante tenha se verificado ampla participação democrática nos trabalhos constituintes, não teve o seu texto final passado pelo crivo popular de forma direta.

Desta feita, e realizadas estas breves e gerais considerações, entendemos ser necessário reconhecer a natureza dinâmica e indomável do Poder Constituinte e, se quisermos almejar uma democracia mais participativa e menos limitada por um sistema puramente representativo, retirar-lhe as amarras jurídicas que o tornam estático. A expressão do Poder Constituinte não se dá unicamente nos momentos de ruptura político-social para a implementação de um novo regime - para logo em seguida voltar ao seu estado de latência -, mas o seu potencial de manifestação é constante e atual, ainda que em graus mais sutis. Assim descreve o professor Francisco de Guimaraens:

"Ebulição. Esta é a sensação que se tem ao se tomar contato com o conceito de poder constituinte, na medida em que se trata de poder exercido de forma sempre atual através da constituição de novos registros de realidade, da instauração de eventos singulares. Poder constituinte é movimento de criação do novo, do original e singular"20

\footnotetext{
19 "Nós, representantes do povo brasileiro, reunidos em Assembleia Nacional Constituinte para instituir um Estado Democrático, destinado a assegurar o exercício dos direitos sociais e individuais, a liberdade, a segurança, o bem-estar, o desenvolvimento, a igualdade e a justiça como valores supremos de uma sociedade fraterna, pluralista e sem preconceitos, fundada na harmonia social e comprometida, na ordem interna e internacional, com a solução pacífica das controvérsias, promulgamos, sob a proteção de Deus, a seguinte CONSTITUIÇÃO DA REPÚBLICA FEDERATIVA DO BRASIL".

${ }^{20}$ GUIMARAENS, Francisco. Op. Cit., p. 83.
} 
Sendo, portanto, o Poder Constituinte - a partir desta constatação conceitual - a expressão da vontade popular, nenhuma Constituição pode ser considerada legítima se não estiver fundada na vontade soberana do povo ${ }^{21}$, de modo que o constitucionalismo é - ou deveria ser, por questão de coerência teórica - inerentemente democrático. Desta forma, constitucionalismo democrático soa, de fato, redundante, uma vez que a gênese de uma Constituição se pressupõe democrática pela própria natureza do Poder Constituinte, entendido como manifestação da vontade do povo, e considerado em toda a sua pluralidade. Contudo, como ainda será abordado no bojo deste trabalho (ver Capítulo 2, tópico 2.3), o termo constitucionalismo democrático ganhou contornos axiológicos para significar a garantia, pelo texto da Constituição, de direitos fundamentais que preservem o caráter democrático dos mecanismos de tomadas de decisão, ainda que em eventual contradição com a manifestação majoritária. Nesta linha, deve haver um equilíbrio entre o poder estatal, normalmente expressão da vontade majoritária, e os direitos fundamentais que asseguram a participação ampla e geral, sem exclusões ou segregações de grupos ou minorias. Assim, o processo de construção de uma sociedade cada vez mais democrática, como assinala José Afonso da Silva, há "de ser um processo de liberação da pessoa humana das formas de opressão que não depende apenas do reconhecimento formal de certos direitos individuais, políticos e sociais, mas especialmente da vigência de condições econômicas suscetíveis de favorecer o seu pleno exercício",22

Neste sentido, advogando por uma radicalização democrática dos meios de participação política, estamos em consonância com esta concepção viva e efervescente de Poder Constituinte. Porém, o reconhecimento da titularidade da Soberania ao povo implica nova questão, fundamental e igualmente problemática no âmbito de qualquer democracia: o conceito de "povo".

\footnotetext{
${ }^{21}$ SILVA, José Afonso da. Poder Constituinte e Poder Popular, op. cit., p. 69.

${ }^{22}$ Ibid. p. 126.
} 


\subsection{O conceito de povo na perspectiva de Friedrich Müller}

A legitimidade democrática do Poder Constituinte reside exatamente na atual ideia de que ele é exercido pelo povo ${ }^{23}$. A soberania popular é, inclusive, reconhecida expressamente no texto da atual Constituição brasileira, no seu art. $1^{\circ}$, Parágrafo Único, ao afirmar que todo o poder emana do povo. Assim, ao elaborar a Constituição, o povo impõe - em tese - a si mesmo e ao seu poder soberano limitações que resguardem o processo político democrático ${ }^{24}$ de eventuais abusos que possam ser realizados em seu nome pelos poderes constituídos. No entanto, antes de adentrar no debate acerca dos possíveis e eventuais caminhos democráticos desenhados por uma Constituição - principalmente no plano da Constituição de 1988 -, faz-se imperiosa a reflexão sobre o conceito de povo e as implicações que o seu papel como titular da soberania e do exercício constituinte ensejam dentro deste contexto.

Obviamente a questão não é simples, e extrapola a matéria de estudo puramente jurídico-política, de modo que o presente trabalho não tem a pretensão de responder a esta pergunta, mas tão somente anotar as ponderações de alguns autores que se debruçaram mais profundamente sobre o tema, em especial as do professor Friedrich Müller.

Dito isto, não obstante o reconhecimento das ambiguidades conceituais, em termos linguísticos, que a palavra "povo" pode gerar, talvez a verdadeira dificuldade resida na constatação do pressuposto lógico de que o povo, sob uma ótica sócio-política, não pode ser entendido como um corpo homogêneo e coeso no âmbito de qualquer sociedade minimamente complexa. Sendo assim, a premissa básica é de que o povo constitui um complexo de forças

\footnotetext{
${ }^{23}$ Nas palavras de José Afonso da Silva: "O que dá essência à democracia é o fato de o poder residir no povo. Toda democracia, para ser tal, repousa na vontade popular no que tange à fonte e exercício do poder, em oposição aos regimes autocráticos em que o poder emana do chefe, do caudilho, do ditador. Vale dizer, portanto, que o conceito de democracia fundamenta-se na existência de um vínculo entre o povo e o poder". Curso de Direito Constitucional Positivo. $35^{\text {a }}$ ed. São Paulo: Malheiros, 2012, p. 133.

${ }^{24}$ BARROSO, Luís Roberto. Op. Cit., p. 155.
} 
políticas plurais ${ }^{25}$. Desenvolvendo esta lógica, salienta o professor Fábio Konder Comparato em prefácio da obra Quem é o Povo? A Questão Fundamental da Democracia, que "povo" não é um conceito unívoco, mas plurívoco ${ }^{26}$.

Desta forma, para efeitos de uma concepção eminentemente democrática, sobretudo de democracia participativa, o conceito de povo também não deve se confundir ao mero "corpo eleitoral”, sob pena de reduzir a ideia de povo a um conceito normativo de titulares do direito de sufrágio, sendo certo que tal visão restritiva não atende à "grandeza pluralística" do povo, que considera uma infinidade de outros elementos para além do povo eleitor $^{27}$. Tal perspectiva é endossada, de certa forma, por José Afonso da Silva, ainda que ele realize uma vinculação enfática do "corpo eleitoral" à classe política:

"Há uma tendência reacionária para reduzir o povo ao conjunto dos cidadãos, ao corpo eleitoral, como se os membros deste fossem entidades abstratas, desvinculadas da realidade que os cerca, como se ao votar o cidadão não estivesse sob a influência de suas circunstâncias de fato e ideológicas [...]. O corpo eleitoral não constitui o povo, mas simples técnica de designação de agentes governamentais. Povo são os trabalhadores. Os titulares do poder dominante (político, econômico e social) não podem entrar no conceito de povo, pois, numa democracia, teriam que ser simplesmente representantes do povo, isto é, os que exercem o poder em nome do povo. O fato de não ser assim na prática concreta das democracias vigentes demonstra apenas que a democracia ainda não atingiu as culminâncias a que sua historicidade aponta." 28

\footnotetext{
${ }^{25}$ CANOTILHO, J. J. Gomes, Direito Constitucional e Teoria da Constituição, 2003, p. 75: “[...] o povo, nas democracias actuais, concebe-se como uma 'grandeza pluralística' (P. Häberle), ou seja, como uma pluralidade de forças culturais, sociais e políticas tais como partidos, grupos, igrejas, associações, personalidades, decisivamente influenciadoras da formação de 'opiniões', 'vontades', 'correntes' ou 'sensibilidades' políticas nos momentos preconstituintes e nos procedimentos constituintes".

${ }^{26}$ Sob a mesma ótica, Norberto Bobbio, O Futuro da Democracia. Tradução de Marco Aurélio Nogueira. 2a ed. São Paulo: Paz e Terra, 2011: “O deslocamento do ângulo visual do Estado para a sociedade civil nos obriga a considerar que existem outros centros de poder além do Estado. Nossas sociedades não são monocráticas mas policráticas. E isto basta para que nos vejamos inesperadamente sobre as areias movediças do pluralismo [...] Inevitável neste ponto, que o problema da democracia encontre e por assim dizer englobe o problema do pluralismo", p. 70.

${ }^{27}$ Ibid. p. 76.

${ }^{28}$ SILVA, José Afonso. Curso de Direito Constitucional Positivo, op. cit., p. 135-136. Ainda sobre este assunto, justifica-se a posição do autor através do seguinte trecho, p. 131: "O regime representativo, no Estado burguês, procura resolver o conflito de interesses sociais por decisões da maioria parlamentar. Maioria que nem sempre exprime a representação da maioria do povo, porque o sistema eleitoral opõe grandes obstáculos a parcela ponderável da população, quanto ao direito de voto, para a composição das Câmaras Legislativas. Daí decorre que a legislação nem sempre reflete aquilo a que a maioria do povo aspira, mas, ao contrário, em grande parte, busca sustentar os interesses da classe que domina o poder e que, às vezes, está em contraste com os interesses gerais da Nação. As classes dirigentes, embora constituindo concretamente uma minoria, conseguem, pelo
} 
Neste contexto, parece se mostrar mais interessante a análise do povo através de uma visão multifacetada, sob os diversos momentos, perspectivas e níveis de atuação que ele pode ensejar numa conjuntura que se pretende democrática. Observando tais elementos, MÜLLER realiza uma abordagem a respeito do conceito de povo apontando suas possíveis e mais marcantes nuances. Assim ele analisa o povo basicamente através de 4 prismas: (a) como povo ativo; (b) como instância global de atribuição de legitimidade; (c) como ícone, e (d) como destinatário de prestações civilizatórias do Estado. Vejamos, em linhas gerais, cada um deles.

O conceito de "povo" como povo ativo tem relação, aproximadamente, com o que já foi aqui exposto. Diz respeito à vinculação da cidadania numa determinada sociedade, ou seja, aos titulares da nacionalidade em um dado Estado a que estão inseridos e, portanto, em pleno gozo de seus direitos civis e políticos no que se refere ao sufrágio e a outros âmbitos de atuação plena na esfera pública. Trata-se de um conceito normativo uma vez que é definido pelo direito positivo, usualmente pela própria Constituição. Assim, estariam excluídos do povo ativo aqueles que, segundo o direito positivo, legitimamente possuem restrições nos seus direitos políticos e civis - como o direito de voto - em razão de condições juspenalistas, faixa etária ou o estado "mental"29, por exemplo.

Ressalta o ilustre doutrinador alemão que, tradicionalmente, tais restrições não são consideradas uma discriminação contrária à democracia, porém, não deixa de questionar a sua legitimidade diante dos critérios de aferição do "povo ativo”, sobretudo quando ligado à nacionalidade. Lembra que a exclusão de estrangeiros - do povo ativo - que vivem no país com o

\footnotetext{
sistema eleitoral, impedir a representação, nos Parlamentos, da maioria do povo, razão por que, fazendo a maioria parlamentar, obtêm uma legislação favorável”.

${ }^{29}$ MÜLLER, Friedrich. Quem é o Povo? A Questão Fundamental da Democracia. Tradução de Peter Naumann; revisão de Paulo Bonavides. Editora Max Limonad, 1998, p. 56-57. Na Constituição brasileira de 1988, a título de exemplo, admite-se a perda ou suspensão dos direitos políticos no seu art. 15, prevendo, inclusive, dentre as hipóteses a condenação criminal transitada em julgado (inciso III) e a incapacidade civil absoluta (inciso II). Já a limitação ao direito de voto em razão da faixa etária está prevista no art. 14, II, somente sendo permitido ao maior de 16 (dezesseis) anos, ainda que facultativamente.
} 
intuito de permanência, trabalham e pagam seus impostos e contribuições, restringe a amplitude e a coerência da justificação democrática ${ }^{30}$, visto que são efetivamente cidadãos e parte integrante da população. Por fim, o "povo" não deveria ser diferenciado segundo o direito eleitoral, ou segundo a disponibilidade de procedimentos representativos ou de qualquer outra natureza normativa ${ }^{31}$, uma vez que tais pressupostos não são capazes de sustentar uma definição autêntica do povo. Diante disso o autor sintetiza:

\begin{abstract}
"A ideia fundamental da democracia é a seguinte: determinação normativa do tipo de convívio de um povo pelo mesmo povo. Já que não se pode ter autogoverno, na prática quase inexequível, pretende-se ter ao menos a autocodificação das prescrições vigentes com base na livre competição entre opiniões e interesses, com alternativas manuseáveis e possibilidades eficazes de sancionamento político. [...]Não há nenhuma razão democrática para despedir-se simultaneamente de um possível conceito mais abrangente de povo: do da totalidade dos atingidos pelas normas: one man one vote. Tudo o que se afasta disso necessita de especial fundamentação em um Estado que se justifica como 'demo' cracia"32
\end{abstract}

Já o "povo" como instância de atribuição não trata do mesmo aspecto que o "povo" enquanto povo ativo, pois o foco é desviado para a ótica da estrutura de legitimação que permeia a atuação dos poderes constituídos do Estado, em especial no que se refere ao exercício de agentes públicos não eleitos. A questão que se coloca é: funcionários públicos, como os juízes ou outros agentes da Administração Pública, que não chegam aos seus cargos por meio de eleição parecem possuir uma relação demasiadamente etérea com o povo no que condiz à legitimidade democrática de sua função ${ }^{33}$. Aqui, é fundamental entender o papel do povo como ponto de partida e ponto de chegada de uma estrutura de legitimação dos agentes públicos que compõe um ciclo de atuação. Explicando: ao mesmo tempo que o povo ativo elege os seus representantes - parlamentares, a rigor -, estes possuem a incumbência de elaborar e produzir as normas que integrarão o ordenamento jurídico; o Poder Judiciário e a Administração Pública que, em geral não dispõem de cargos eletivos, são os órgãos responsáveis pela aplicação das normas

\footnotetext{
${ }^{30}$ Ibid. p. 57.

${ }^{31}$ Ibid. p. 58.

${ }^{32}$ Ibid. p. 57-58.

${ }^{33}$ Ibid. p. 59.
} 
produzidas pelo Poder Legislativo; os destinatários da aplicação das normas por esses aparelhos de Estado são potencialmente todos, ou seja, justamente o povo. Veja-se que o povo atua como povo ativo, originador dessa sucessão de atos, mas também cumpre o seu papel como destinatário final dos mesmos, formando um ciclo de atos que MÜLLER denomina estrutura de legitimação. ${ }^{34}$

Nesse contexto, o povo é visto como instância global da atribuição de legitimidade democrática, visto que, ainda que algumas funções públicas do Estado não retirem seu fundamento de legitimidade através de uma atuação imediata do Soberano, adquirem-na de maneira mediata. Há que se admitir, é verdade, certa interrupção do ciclo de legitimidade, porém isto não significa que tal interrupção seja não-democrática ${ }^{35}$, já que prevista dentro das normas que estruturam organização do Estado Democrático de Direito.

Aqui é possível observar também uma clara abstração normativa, pois se admite que todo o poder emana do povo, mas que nem todo o poder de Estado efetivamente está no povo; não obstante este poder seja exercido "em seu nome" para fins de legitimação. Contudo, salienta MÜLLER que "esse entendimento é defensável somente onde ele é simultaneamente real: não em sistemas autoritários, onde o 'povo' é fartamente invocado como instância de atribuição, ao passo que depois só tem (des)valor ideológico, não mais função jurídica. A figura da instância de atribuição justifica - embora de maneira sui generis - somente onde está dada ao mesmo tempo a figura do povo ativo"36.

Nesta linha, o povo ativo mostra-se como elemento fundamental para que o povo de atribuição se sustente e, como dito, razão pela qual não é possível justificar os regimes autoritários como legítimos. No entanto, tal circunstância não deixa de ser possível mesmo num cenário de democracia. Ou seja, quando apesar da "roupagem" democrática da estrutura estatal os procedimentos implementados na prática não o são ${ }^{37}$, paradoxalmente,

\footnotetext{
${ }^{34}$ Ibid. p. 60.

${ }^{35}$ Ibid. p. 60.

${ }^{36}$ Ibid. p.63.

${ }^{37}$ Ibid. p. 65-66: "Pois o que deve valer se a constituição invoca no seu texto o poder constituinte do povo, mas essa constituição - como aconteceu no caso da Lei Fundamental alemã - é posta em
} 
mediante a justificativa de que a atuação ilegítima se fez "em nome do povo". Tem-se, no caso, o povo como ícone. Em outras palavras, invoca-se o "povo" para se legitimar certa situação irregular em termos democráticos. Nesta hipótese o conceito não passa de uma generalização fictícia. O povo icônico não é real, não se trata nem do povo ativo nem no povo de atribuição, pois o "povo de fato" nem mesmo está exercendo a dominação real ${ }^{38}$. A iconização consiste, portanto, na tentativa de unificar em "povo" a uma população diferenciada $^{39}$ para fins ideológicos de legitimação precária. Para tanto, MÜLLER destaca a relevância da ação real do povo como sujeito fiscalizador das instituições e procedimentos democráticos:

"Mas se o povo - mesmo no conjunto normativamente restrito de povo ativo - deve
apresentar-se como sujeito político real, fazem-se necessárias instituições e, por
igual [nicht zuletzt], procedimentos: a eleição de uma assembleia constituinte, o
referendo popular sobre o texto constitucional, instituições jurídicas plebiscitárias,
eleições livres e destituição por meio do procedimento plebiscitário [Abwahl] e
votação. As alternativas e sanções devem ser normatizadas de forma cogente no
tocante aos procedimentos. A pequena lâmpada diante do ícone pode extinguir-se; o
povo - nem que seja apenas o seu conjunto parcial dos cidadãos titulares de direitos
ativos - entra em cena como destinatário e agente de responsabilidade e controle."

Por fim, o povo como destinatário de prestações civilizatórias do Estado pode ser traduzido, de forma sintética, na ideia do "povo" como a totalidade dos efetivamente atingidos pelo direito vigente e pelos atos decisórios do poder estatal ${ }^{41}$. Aqui é possível observar mais nitidamente a interação recíproca Estado-sociedade em sua faceta tipicamente

\footnotetext{
vigor sem um procedimento democrático? E o que vale, se as leis parlamentares são promulgadas corretamente, mas se o parlamento não é 'representativo' - em virtude de eleições fraudadas ou em virtude da manipulação do procedimento de votação ou por razões similares, quer genericamente, quer no caso em questão? [...]O que deve valer, se leis legítimas ou decretos não são implementados pelo governo ou pela administração pública ou se sua realização se desencaminha subjetiva ou objetivamente, ou de qualquer modo objetivamente? E o que deve valer - com vistas à legitimação democrática -, se a justiça decide com caráter de obrigatoriedade 'em nome do povo', mas se a sentença judicial não pode ser atribuída com plausibilidade a nenhuma lei vigente [...]".

${ }^{38}$ Ibid. p. 67.

${ }^{39}$ Neste sentido, explica Müller que a "população heterogênea é 'uni'ficada em benefício dos privilegiados e dos ocupantes do establishment, é ungida como 'povo' e fingida - por meio do monopólio da linguagem e da definição nas mãos do(s) grupo(s) dominante(s) - como constituinte e mantenedora da constituição. Isso impede, conforme se deseja, de dar um nome às cisões sociais reais, de vivê-las [austragen] e consequentemente trabalha-las. A simples fórmula do "poder constituinte do povo' já espelha ilusoriamente o uno", ibid. p. 72-73.

${ }^{40}$ Ibid. p. 73.

${ }^{41}$ Sendo, segundo Müller, essa "totalidade entendida como a das pessoas que se encontrem no território do respectivo Estado", ibid. p. 76.
} 
verticalizada. Quer dizer, o Estado invoca o "povo" para legitimá-lo, ao passo que o povo demanda, em contrapartida, as prestações públicas que cabem ao Estado de maneira vinculada conforme as prescrições do ordenamento jurídico. Assim, esses dois elementos são necessariamente abarcados numa cultura jurídica democrática: a coparticipação do povo nos processos políticos de tomada de decisão e a implementação dessas decisões enquanto efeitos produzidos sobre o próprio povo ${ }^{42}$. Desta forma, o grau de atuação do povo-destinatário diz respeito à observância da cidadania pelo Estado, ainda que não se reduza somente a isto, uma vez que na conjuntura constitucional e internacional contemporânea, o respeito aos direitos fundamentais e a defesa dos direitos humanos se fazem imprescindíveis para uma democracia legítima.

A esta altura já é possível notar as diversas gradações e perspectivas que o prefixo do termo "democracia" pode ensejar apenas sob o olhar da ciência do direito. Sendo assim, é evidente que a análise do conceito de "povo" será realizada a partir do prisma jurídico-normativo e menos de um ângulo filosófico-sociológico, porém sem perder inteiramente o caráter multidisciplinar que o tema necessariamente exige. Percebe-se, desta forma, que as dificuldades relativas ao conceito de povo para a ciência jurídica são relativamente as mesmas dificuldades que o direito possui, em geral, na sua relação com a realidade fática, ou seja, entre a clássica dicotomia ser-dever ser. Seguindo este raciocínio, segundo o professor MÜLLER, "quanto mais o 'povo' for idêntico com a população no direito efetivamente realizado de uma sociedade constituída, tanto mais valor de realidade e consequentemente de legitimidade terá o sistema democrático existente como forma” ${ }^{\star 43}$.

\footnotetext{
42 Ibid. p. 77. Na mesma linha, ver também Samantha Chantal Drobrowolski, A Construção Social do Sentido da Constituição na Democracia Contemporânea: entre Soberania Popular e Direitos Humanos, Rio de Janeiro, Lumen Juris: 2007, em tópico sobre o nexo interno entre direitos humanos e soberania popular no pensamento habermesiano: "Portanto, como co-autores e destinatários das normas jurídicas que regem a vida social, em uma sociedade democrática, os cidadãos têm que poder exercer, em concomitância, seus direitos privados, que lhes garantem sua condição de indivíduos livres e iguais, e seus direitos de participação política, que lhes conferem a marca própria da cidadania, sob forma de parceiros co-associados de uma mesma ordem normativa por eles estabelecida", p. 192.

${ }^{43}$ Ibid. p. 111.
} 
Ante o exposto, é notório que o povo se apresenta dentro do contexto de democracia sob diversos graus de operações de legitimação e, do ponto de vista jurídico-normativo, como uma multiplicidade em si diferenciada, mista, constituída em grupos, mas organizada de forma igualitária e nãodiscriminatória ${ }^{44}$.

\subsection{A soberania popular no modelo deliberativo-procedimental de democracia de Jürgen Habermas}

Como já aludido, o modelo de democracia amplamente participativa elaborado por ROUSSEAU, precursor eminente da consciência revolucionária, concebia o estabelecimento da soberania popular como um ato de sociabilização, mediante o qual os indivíduos isoladamente considerados transformam-se em cidadãos virtuosos orientados para o interesse e o bem comum ${ }^{45}$, resultando na manifestação da vontade geral do povo $^{46}$. Obviamente, na concepção do iluminista, o "bem comum" seria uma constatação lógica atingida através do pensamento racional, uma vez que conduzidos pelos valores substanciais e universais que, na época, eram preconizados metafisicamente pelo direito natural.

O caráter utópico desta construção teórica torna-se evidente à medida em que se observa que a modernidade tem como referencial histórico exatamente a constatação da ruptura da tradição - do ponto de vista hegemônico ocidental -, em outras palavras, esta ruptura significa o esvaziamento dos valores metafísicos, éticos e religiosos, em decorrência do descrédito e da incapacidade dos mesmos em explicar a complexidade e multiplicidade que a nova conjuntura sócio-política da realidade moderna e pós-moderna (ou contemporânea) exigia. Soma-se a isto o fato de que, nas

\footnotetext{
${ }^{44}$ Ibid. p. 109.

${ }^{45}$ HABERMAS, Jürgen. Soberania Popular como Procedimento: um conceito normativo de espaço público. Tradução de Márcio Suzuki. Novos Estudos CEBRAP nº 26, 1990, p. 102.

${ }^{46}$ Neste sentido, Rousseau, no Capítulo III do Livro II do O Contrato Social: "Se, quando o povo suficientemente informado delibera, os cidadãos não tivessem nenhuma comunicação entre si, do grande número de pequenas diferenças resultaria sempre a vontade geral e a deliberação seria sempre boa".
} 
sociedades complexas contemporâneas sobressalta-se justamente, como já visto, a característica do pluralismo ${ }^{47}$, ao passo que a ficção rousseauniana da vontade popular única suprime precisamente essa heterogeneidade das vontades individuais ${ }^{48}$. Neste ínterim, Gisele Cittadino aborda didaticamente a perspectiva habermesiana:

"Habermas, como vimos, toma o pluralismo - tanto o da diversidade das concepções individuais sobre o bem, como o da multiplicidade das identidades sociais - como uma das marcas definitórias das democracias contemporâneas. A identidade pósconvencional é fruto, portanto, da inexistência de visões éticas, religiosas ou tradicionais de mundo que possam configurar um sistema de valores compartilhados capaz de estabelecer um consenso básico entre os cidadãos. O pluralismo social, o pluralismo cultural e o pluralismo dos projetos pessoais de vida transformam a modernidade em um mundo desencantado onde os indivíduos relacionam-se entre si enquanto estranhos." 49

Sendo assim, a indagação habermesiana surge para tentar solucionar o problema que um povo plural, heterogêneo e descrente de valores substanciais que tenham o condão de unificar os indivíduos a partir de uma moralidade minimamente coletiva, naturalmente enseja, em termos de integração social capaz de propiciar a livre opinião e vontade política para fins de legitimação democrática da atuação dos poderes do Estado. Diante deste cenário, HABERMAS reconhece no Direito o único instrumento apto a regular normativamente as relações e interações entre os cidadãos nas democracias contemporâneas. Contudo, como salienta DOBROWOLSKI,

\footnotetext{
${ }^{47}$ De acordo com J. J. Gomes Canotilho, no âmbito da "teoria normativa - o pluralismo como ideia dirigente - a teoria pluralista pressuporia um sistema político aberto, com ordens de interesses e valores diferenciados e que, tendencialmente, permitiria a todos os grupos a chance de influência efectiva nas decisões políticas", contudo, ele também ressalta as críticas à teoria pluralista da democracia, dentre as quais se destaca a de que "a teoria pluralista não demonstrou terem os diferentes grupos iguais oportunidades de influência política, e deixa pouco esclarecido o modo como se faz a articulação dos interesses destes vários grupos na formação de decisão", op. cit., p. 1409-1410. Contudo, lembra Bobbio que "antes de ser uma teoria, o pluralismo é uma situação objetiva, na qual estamos imersos", op. cit., p. 71.

${ }^{48}$ HABERMAS, Jürgen. Op. Cit., p. 102.

${ }^{49}$ CITTAdinO, Gisele. Pluralismo, Direito e Justiça Distributiva: elementos da filosofia constitucional contemporânea. $4^{\text {a }}$ ed. Rio de Janeiro: Lumen Juris, 2009, p. 170-171. Na mesma linha, Samantha Chantal Dobrowolski: "O pluralismo reforça, no mundo contemporâneo, os efeitos do processo de desencantamento produzido pela racionalização e secularização modernas. Intensifica a fluidez dos marcos referenciais e a constante renovação dos horizontes de sentido, ou, ao menos, impõe permanentemente a abertura da sociedade e do Estado a novos questionamentos, a novos modos de vida e de produção de subjetividade. Talvez resida, nisto, sua contribuição maior à causa da democracia, pois a heterogeneidade de que é tributário permite a experiência da inovação e da indeterminação, traços ínsitos à natureza dinâmica e aberta da forma de sociedade democrática", op. cit., p. 196.
} 
"sobre a democracia, recai todo o exigente ônus de legitimação da ordem social, o que requer a adoção de procedimentos cujos resultados possam ser aceitos como racionais, embora, por sua falibilidade potencial, não possam ser tomados como automática e incontestavelmente válidos - como, aliás, sói acontecer em sociedades pluralistas pós-tradicionais e pós-convencionais"50. Desta premissa, HABERMAS busca inspiração na doutrina de Julius Fröbel (1847), democrata sul-alemão, que recorre a condições de comunicação sob as quais a formação de opinião orientada pela verdade pode ser combinada com a formação de vontade majoritária, numa interessante ligação do princípio da livre discussão ao princípio da maioria: ${ }^{51}$

"Ao contrário do que fizera Rousseau com a mera forma da lei universal, Fröbel não implanta a razão prática na vontade soberana de um coletivo, mas a apóia num procedimento de formação de opinião e de vontade que estabelece quando uma vontade política, que não é idêntica à razão, tem seu a lado a suposição da razão. $\mathrm{O}$ estabelecimento majoritário de uma vontade unitária só é conciliável com o 'princípio da igual validade da vontade pessoal de todos' se ligado ao princípio de 'afastar o erro pela via da persuasão'. E este princípio pode afirmar-se contra maiorias tirânicas apenas em discursos públicos". 52

Seguindo essa linha, HABERMAS transfere a centralidade de qualquer elemento de valor ou direito substancial do plano da legitimidade democrática, atribuindo ao procedimento adequado a produção das normas jurídicas o protagonismo na esfera de um Estado de Direito que tem como prerrogativa a relação inerente com a democracia ${ }^{53}$. Neste sentido, ressalta DOBROWOLSKI que:

"[...] dado o fato do pluralismo e a ausência de certezas, que caracterizam as condições de pensamento pós-metafísico, não se pode obter consenso sobre o conteúdo, mas apenas sobre o procedimento - democrático -, capaz de gerar normas jurídicas legítimas. Deste modo, a racionalidade procedimental passa a constituir a "única dimensão na qual se pode atribuir ao direito positivo um momento de

50 DOBROWOLSKI, Samantha Chantal. A Construção Social do Sentido da Constituição na Democracia Contemporânea: entre a soberania popular e os direitos humanos. Rio de Janeiro: Lumen Juris, 2007, p. 181.

${ }^{51}$ HABERMAS, Jürgen. Op. Cit., p. 103.

52 Ibid. p. 104, complementando ainda, na mesma página, que os "princípios constitucionais de Fröbel retiram toda a ideia de substância da ordem constitucional; de uma maneira rigorosa pósmetafísica, eles não indicam nenhum 'direito natural', mas apenas o procedimento de uma formação de opinião e vontade que assegura liberdades iguais sobre os direitos universais de comunicação e participação".

${ }^{53}$ Ver CANOTILHO, J. J. Gomes. Op. Cit., p. 1416-1417. 
aceitabilidade racional, de validade e de indisponibilidade, a qual ultrapassa o nível das meras contingências factuais tocando em aspectos morais". 54

No entanto, essa legitimação democrática pelo procedimento pressupõe como fundamento nuclear, para que as deliberações realizadas no âmbito de uma esfera pública ${ }^{55}$ adquiram feições de validade, a suposição de que a ação comunicativa do corpo social não seja orientada pelo sistema político, já que isso implicaria viciar o seu caráter autônomo de formação de opinião e de vontade. Em vista disso, é preciso observar certas premissas para a preservação das condições básicas para que o procedimento mantenha sua presunção de racionalidade e discursividade. Neste sentido, o Estado deve buscar assegurar, através de um sistema de direitos, ao mesmo tempo, a autonomia privada dos indivíduos, de que decorrem as liberdades subjetivas de ação, e a autonomia pública dos sujeitos de direito - da que se originam seus direitos políticos de cidadania -, o que requer instâncias prévias de discussão pública que servem de balizamento para o poder comunicativo voltado ao entendimento ${ }^{56}$. Evidencia-se, neste quadro, o nexo intrínseco entre o Estado de Direito e democracia.

É preciso, porém, antes de prosseguir, fazer um destaque à relevância dos direitos que resguardam a autonomia privada, em face da esfera

\footnotetext{
${ }^{54}$ DOBROWOLSKI, Samantha Chantal. Op. Cit., p. 188. Ainda sobre isso, Bobbio, ao mencionar que é ínsito à democracia pluralista pressupor o dissenso, requerendo apenas o consenso, de modo geral, no que diz respeito às "regras do jogo" democrático, op. cit., p. 74.

${ }^{55}$ Samantha Dobrowolski explica, em minuciosa e didática nota de rodapé, o conceito de esfera pública dentro da teoria habermesiana: "Nas sociedades complexas, a esfera pública configura uma estrutura intermediária entre sociedade civil e sistema político. [...] Trata-se de uma rede supercomplexa que se ramifica espacialmente em diversas arenas internacionais, nacionais, regionais, comunais e subculturais, que se sobrepõe umas às outras, se articulam e diferenciam, formando esferas públicas mais ou menos especializadas, mas ainda acessíveis aos leigos (literárias, artísticas, feministas, científicas, alternativas, de políticas de saúde, ecológicas, clericais etc.). Podem ser constatadas três diferentes espécies de esfera pública, consoante sua complexidade organizacional, alcance e densidade da comunicação: episódica (bares, cafés etc.), de presença organizada (reunião de pais, de partidos e de igrejas, frequência de shows e teatros, por ex.), e a abstrata, produzida pela mídia (público espalhado globalmente). [...] [Habermas] entende que a opinião pública pode surgir no momento em que pessoas informadas, inclusive sobre as decisões políticas e seus correlatos e antecedentes processos de discussão, tornam-se aptas a formar juízos fundamentados sobre assuntos de interesse geral, através do debate intersubjetivo em foros abertos. O caráter público da opinião pressupõe que seu resultado, compartilhado intersubjetivamente, decorra de um processo de discussão - o qual, após seu giro jurídico-linguístico, Habermas considera deva consistir em uma interação dialógica voltada ao entendimento, para, nesta medida, adquirir certo viés racional", ibid., p. 203-204.
}

${ }^{56}$ Ibid. p. 189. 
institucional política, para amparar as interações horizontais inerentes à prática intersubjetiva de deliberação e para a formação de "associações livres que constituem os entrelaçamentos de uma rede de comunicação que surge do entroncamento de espaços públicos autônomos" ${ }^{\text {"27 }}$, que só pode ser proporcionado por uma esfera privada minimamente protegida - como, por exemplo, liberdades de expressão, associação, reunião e imprensa - para que os cidadãos, na condição de livres e iguais ${ }^{58}$ possam, a partir disso, exercer com plenitude os seus direitos de participação no campo da autonomia pública ${ }^{59}$.

Feito este adendo, configura-se notável que a obtenção do resultado almejado pelo modelo deliberativo-procedimental habermesiano no contexto de uma sociedade democrática somente pode ser concretizado por meio da implantação e observância de um sistema de direitos. É dizer: a carga de legitimação da normatização das qualificações jurídicas dos cidadãos desloca-se para os procedimentos de formação democrática da opinião e da vontade, também institucionalizada através do direito ${ }^{60}$. Em consonância com esta perspectiva, CITTADINO afirma que:

"Ao basear a legitimidade do direito nos procedimentos democráticos de elaboração legislativa, Habermas revela o seu compromisso com o processo político deliberativo, no qual o debate argumentativo assegura a formação da vontade de cidadãos plenamente autônomos, capazes de autorrealização e de autodeterminação. Neste sentido, há, de acordo com Habermas, uma relação interna, conceitual, entre

\footnotetext{
${ }^{57}$ HABERMAS, Jürgen. Op. Cit., p.110.

${ }^{58}$ Especificamente sobre isso, uma visão realista de Guillermo O'Donnell, em Uma outra Institucionalização: América Latina e alhures. Lua Nova nº 37, 1996: "A situação como um todo resulta em uma disjunção que, vista à luz da experiência histórica da maioria das poliarquias formalmente institucionalizadas, parece estranha. Nos países de que ora nos ocupamos, as liberdades mais políticas, democráticas, são efetivas. Isso diz respeito à ausência de coerção sobre o voto e às liberdades de opinião, de movimento, de associação e outras já enumeradas. Mas para diversos segmentos da população, são negadas ou espezinhadas as liberdades liberais fundamentais. Os direitos de mulheres espancadas de processar seus maridos, de camponeses de conseguir um julgamento justo contra seus patrões proprietários de terras, a inviolabilidade de domicílio em bairros pobres e, de forma geral, o direito do pobre e de várias minorias a um tratamento decente e a um acesso equitativo a agências públicas e aos tribunais são frequentemente violados. A efetividades do conjunto todo de direitos, democráticos e liberais, contribui para uma cidadania civil e política plena", p. 28-29.

${ }^{59}$ Sob esta lógica, Gisele Cittadino expõe que a "ideia fundamental de Habermas é que a conexão interna entre autonomia privada e autonomia pública não pode ser estabelecida caso os cidadãos não reconheçam a existência de um sistema de direitos quando pretendem legitimamente regular as suas relações através do direito positivo", op. cit., p. 174.

${ }^{60}$ DOBROWLSKI, Samantha Chantal. Op. Cit., p. 195.
} 
direito e democracia, que se traduz na conexão intrínseca entre direitos humanos e soberania popular". 61

Com efeito, é possível, a esta altura, traçar um paralelo conceitual com a ideia do povo como instância global de atribuição de MÜLLER ${ }^{62}$ ao vislumbrar que os cidadãos, ao participar da elaboração das leis que regem sua vida coletiva através de um procedimento comunicativo-discursivo no âmbito de um espaço público, devem efetivamente sentir-se, simultaneamente, como autores e destinatários coassociados de uma mesma ordem normativa por eles estabelecida, dinamizando desta forma o ciclo da estrutura de legitimação. Esta é a força socialmente integradora que o direito positivo é capaz de produzir no horizonte das sociedades contemporâneas. Entretanto, HABERMAS ressalta enfaticamente que essa "ideia de um atuar sobre si mesmo por meio de leis só é plausível a partir da suposição de que no conjunto a sociedade pode ser representada em geral como uma associação que determina para si o próprio direito e o poder político através dos meios" $"$.

Dadas estas circunstâncias, é importante frisar que, para a teoria habermasiana, uma vez reconhecida a complexidade das sociedades contemporâneas e o estabelecimento hegemônico do Estado Democrático de Direito, o papel das instituições ${ }^{64}$ é considerado imprescindível, uma vez que

“[...] o Estado de direito democrático tornou-se projeto, a um tempo resultado e catalisador de uma racionalização do mundo da vida que ultrapassa de longe o político. O único conteúdo do projeto é a institucionalização aprimorada passo a passo do procedimento de formação racional da vontade coletiva, procedimento que não pode prejudicar os objetivos concretos dos envolvidos. Cada passo neste caminho tem efeitos retroativos na cultura política e nas formas de vida; todavia,

\footnotetext{
${ }^{61}$ CITTADINO, Gisele. Op. Cit., p. 173.

${ }^{62}$ Ver tópico 1.2 deste trabalho.

${ }^{63}$ HABERMAS, Jürgen. Op. Cit., p. 108.

${ }^{64}$ O'DONNELL, Guillermo, Op. Cit., p. 10: “Por 'instituição' entendo um padrão regulado de interação que é conhecido, praticado e aceito (ainda que não necessariamente aprovado) pelos atores que têm a expectativa de continuar interagindo sob as normas sancionadas e garantidas por esse padrão". Associando normalmente o maior grau de institucionalização como sendo diretamente proporcional à consolidação da democracia: "Quando as eleições estão institucionalizadas, pode-se dizer que a poliarquia, ou a democracia, está 'consolidada' [...] Outros autores propõem definições ampliadas de consolidação democrática, muitas delas centradas na realização de um grau elevado de 'institucionalização'. Em geral essas definições não vêem as eleições como uma instituição. Elas enfocam as organizações formais, basicamente o executivo, os partidos, o congresso e às vezes o judiciário", p. 12-13.
} 
sem o concurso não intencional destas não podem surgir formas de comunicação adequadas à razão prática." ${ }^{\circ 5}$

Desta forma, poderia se dizer que o poder administrativo - traduzido na atuação genérica das instituições jurídico-políticas - consiste no poder exercido de fato, capaz de gerar resultados concretos e imediatos na realidade social, ao passo que o poder comunicativo funda-se na interação discursiva dos indivíduos, que deliberam autônoma e racionalmente no plano do espaço público. Assentado isto, podemos distinguir, segundo HABERMAS, o "poder gerado de maneira comunicativa e o poder utilizado administrativamente. No espaço público político entrecruzam-se então dois processos em sentidos opostos: a geração comunicativa do poder legítimo, para o qual Hannah Arendt esboçou um modelo normativo, e a obtenção de legitimação pelo sistema político, com a qual o poder administrativo é refletido"66. Em outras palavras, sem a prévia deliberação promovida pelo poder comunicativo, nos moldes dos procedimentos democráticos juridicamente previstos, padece de legitimidade qualquer ação do poder administrativo das instituições - em ultima ratio no plano das atividades típicas do Executivo, Legislativo ou Judiciário.

Diante desta configuração teórica, não se pode deixar de observar que HABERMAS tenta a todo momento validar o exercício dos Poderes Constituídos, representado justamente pelas instituições, ao buscar vinculálo à atuação do Poder Constituinte, ou seja, do povo - ou do conjunto de cidadãos - enquanto delibera sobre as questões essenciais e de interesse geral; ainda que esse agir do Poder Constituinte não seja aqui na sua forma originária ou ilimitada, uma vez que restringido pelos procedimentos e pelo direito positivo - e portanto desempenhado na sua forma mais sutil -, coaduna-se com o que já foi abordado anteriormente, a respeito da natureza

\footnotetext{
${ }^{65}$ HABERMAS, Jürgen. Op. Cit., p. 112.

${ }^{66}$ Ibid. p. 108. Complementa o próprio Habermas que "como os dois processos - a formação espontânea de opinião em espaços públicos autônomos e a obtenção organizada de lealdade das massas - se interpenetram, e quem domina quem, é uma questão empírica”.
} 
sempre dinâmica e efervescente do mesmo, e como elemento de legitimidade do ordenamento jurídico posto.

Sob este prisma, salienta Gisele Cittadino que:

"[...] o Estado Democrático de Direito, ao institucionalizar as práticas de autodeterminação cidadã, assegura, ao mesmo tempo, a ideia republicana de "democracia radical", segundo a qual os debates argumentativos que se processam no âmbito da sociedade civil - na "periferia" - podem influenciar as deliberações e decisões tomadas no "centro", isto é, pelo sistema político enquanto poder administrativo. E o direito, segundo Habermas, é o meio através do qual o poder administrativo é programado e controlado pelo poder comunicativo dos cidadãos. Com efeito, se o direito é o resultado de um entendimento entre os cidadãos sobre a forma como devem ser legitimamente regular as suas relações, o sistema administrativo - regido por um código de poder - deve, em um Estado Democrático de Direito, estar vinculado "ao poder comunicativo de formação do direito e se manter livre das intervenções ilegítimas de poder social."

Em suma, HABERMAS vislumbra, no contexto pluralista das sociedades contemporâneas, uma concepção democrática deliberativoprocedimental que pressupõe a auto-organização da comunidade, através de processos públicos de formação da opinião e da vontade comuns, em que valores, perspectivas e projetos divergentes podem ser racional e livremente debatidos e negociados. Para tanto, é necessária a institucionalização jurídica de diferentes formas de comunicação e deliberação ${ }^{68}$.

Neste ínterim, a ideia de soberania popular rousseauniana é dessubstanciada pelo modelo procedimental habermasiano. Este preconiza que numa "época de política inteiramente secularizada, não se pode ter nem manter um Estado de direito sem democracia radical" ${ }^{\prime 69}$, e para tanto, sublinha HABERMAS que a soberania:

“[...] dissolvida (verflüssigt) comunicativamente faz-se valer no poder dos discursos públicos, que nasce de espaços autônomos, mas tem de tomar forma nas decisões de instituições de formação de opinião e vontade concebidas democraticamente, porque a obrigação de responder pelas decisões requer uma responsabilidade institucional clara. O poder comunicativo é exercido no modo de assédio. Ele atua sobre as premissas dos processos decisórios do sistema administrativo sem intenção de

${ }^{67}$ CITTADINO, Gisele. Op. Cit., p. 179-180.

${ }^{68}$ DOBROWOLSKI, Samantha Chantal. Op. Cit., p. 202, e assim, "considera que os direitos mecanismos contramajoritários, isto é, meios de defesa usualmente utilizados pelas minorias contra abusos das maiorias legislativas -, e a democracia - sistema operativamente regulado pela regra da maioria, como expressão da soberania popular, embora com a preservação das minorias -, não se opõe, mas se pressupõe e complementam reciprocamente [...]", ibid. p. 200.

${ }^{69}$ HABERMAS, Jürgen. Direito e Democracia: entre facticidade e validade. Tradução de Flávio Beno Siebeneichler. Rio de Janeiro: Tempo Brasileiro, 1997, vol. 1, p. 13. 
conquista, a fim de apresentar seus imperativos na única linguagem que a cidadela sitiada entende: ele gere o pool de fundamentos com os quais o poder administrativo pode lidar instrumentalmente, sem contudo poder ignorá-los tais como são concebidos juridicamente (rechtsförmig)., ${ }^{, 70}$

\subsection{A Constituição de 1988 e a democracia participativa}

É conhecida a célebre formulação de Abraham Lincoln ao definir a democracia como "governo do povo, pelo povo e para o povo". Assim, a positivação do princípio democrático no texto da Constituição da República de 1988 não consiste na mera adoção de uma teoria em abstrato, mas, uma vez reconhecida sua força normativa, conforme explica CANOTILHO, procura uma ordenação normativa para um país e para uma realidade histórica $^{71}$. Nesta linha, continua o ilustre constitucionalista português, os desdobramentos do princípio democrático "acolhe os mais importantes postulados da teoria democrática representativa - órgãos representativos, eleições periódicas, pluralismo partidário, separação de poderes", assim como "implica democracia participativa, isto é, a estruturação de processos que ofereçam aos cidadãos efectivas possibilidades de aprender a democracia, participar nos processos de decisão, exercer controlo crítico na divergência de opiniões, produzir inputs políticos democráticos"72.

O que se pode notar, através do texto do Parágrafo Único do art. $1^{\circ}$ da Constituição, é que, na esteira da maioria das democracias ocidentais, pretendeu-se reunir elementos das chamadas democracia representativa (ou indireta) e democracia direta. Cabe transcrevê-lo:

"Art. $1^{\circ} . \ldots$

Parágrafo único. Todo o poder emana do povo, que o exerce por meio de representantes eleitos ou diretamente, nos termos desta Constituição".

Segundo Norberto Bobbio, a expressão "democracia representativa" significa genericamente que as deliberações coletivas, isto é, as deliberações

\footnotetext{
${ }^{70}$ HABERMAS, Jürgen. Soberania Popular como Procedimento..., op. cit., p. 111.

${ }^{71}$ CANOTILHO, J. J. Gomes. Op. Cit., p. 287.

${ }^{72}$ Ibid. p. 288.
} 
que dizem respeito à coletividade inteira, são tomadas não diretamente por aqueles que dela fazem parte mas por pessoas eleitas para esta finalidade ${ }^{73} \mathrm{e}$, desta forma, pressupõe um conjunto de instituições que disciplinam a participação popular no processo político - de forma indireta, periódica e formal -, que vem a formar os direitos políticos que qualificam a cidadania, tais como as eleições, o sistema eleitoral, os partidos políticos etc., como constam, no caso da Constituição de 1988, nos arts. 14 a $17 .{ }^{74}$

Por outro lado, por democracia direta se entende quando o indivíduo participa ele mesmo nas deliberações que lhe dizem respeito, ou seja, que entre os indivíduos deliberantes e a deliberação não exista nenhum intermediário $^{75}$. Obviamente, como já ilustrado, na sociedade global contemporânea, dada a sua complexidade, extensão territorial dos Estados e grandeza populacional, o uso exclusivo desse tipo de democracia como forma de governo não é apenas materialmente impossível como também insensato, ressalta BOBBIO. Portanto, é compreensível que no modelo hegemônico de democracia no mundo contemporâneo prevaleça uma estrutura predominantemente representativa. Para além da mera perspectiva da viabilidade prática, Boaventura de Sousa Santos traz outra visão, de cunho sociológico, para explicar este fenômeno:

“[...] as sociedades capitalistas, sobretudo nos países centrais, consolidaram uma concepção hegemônica de democracia, a concepção da democracia liberal com a qual procuraram estabilizar a tensão controlada entre democracia e capitalismo. Essa estabilização ocorreu por duas vias: pela prioridade conferida à acumulação de capital em relação à redistribuição social e pela limitação da participação cidadã, tanto individual, quanto coletiva, com o objetivo de não 'sobrecarregar' demais o regime democrático com demandas sociais que pudessem colocar em perigo a prioridade da acumulação sobre a redistribuição. O receio da 'sobrecarga democrática' presidiu as transformações que, a partir da década de 1980, se deram na teoria e na prática democráticas hegemônicas nos países centrais, depois exportadas para a semiperiferia e periferia do sistema mundial". ${ }^{76}$

\footnotetext{
${ }^{73}$ BOBBIO, Norberto. O Futuro da Democracia. Tradução de Marco Aurélio Nogueira. $2^{\text {a }}$ ed. São Paulo: Paz e Terra, 2011, p. 56.

${ }^{74}$ SILVA, José Afonso. Curso de Direito Constitucional Positivo, op. cit., p. 137.

${ }^{75}$ BOBBIO, Norberto. Op. Cit., p. 63.

${ }^{76}$ SANTOS, Boaventura de Sousa et al.. Democratizar a Democracia: os caminhos da democracia participativa. Rio de Janeiro: Civilização Brasileira, 2002, p. 59. E ressalta ainda este autor, expondo a justificação dessa lógica, que "a sobrecarga era causada pela inclusão política de grupos sociais anteriormente excluídos e pelas demandas 'excessivas' que faziam à democracia", assim, "a
} 
Todavia, a democracia vista como processo dinâmico inerente a uma sociedade aberta e ativa deve oferecer aos seus cidadãos a possibilidade de desenvolvimento integral e de liberdade de participação crítica no processo político, se interpretada nos moldes dos preceitos constitucionais de construção de uma sociedade livre, justa e solidária (art. $3^{\circ}$, I, da CRFB/88). ${ }^{77}$ Não obstante, a Constituição de 1988 prevê sistematicamente uma ampla e diversificada gama de espaços públicos para uma efervescente participação popular, dentre os quais, podemos mencionar, exemplificativamente, a participação nos órgãos públicos colegiados em que seja objeto de discussão e deliberação os interesses profissionais e previdenciários dos trabalhadores e empregadores (art. 10); a participação do usuário na Administração Pública direta e indireta (art. $37, \S 3^{\circ}$ ); representação de qualquer cidadão perante o Poder Legislativo (art. 58, §2 , IV) ou perante o Tribunal de Contas da União (art. 74, §2º); participação nos Conselhos da República (art. 89, VII), do Meio Ambiente, da Educação, da Saúde, da Assistência Social, Tutelar, Penitenciário entre outros; participação dos produtores e trabalhadores rurais no planejamento e execução da política agrícola (art. 187); participação quadripartite dos trabalhadores, empregadores, aposentados e do Governo nos órgãos colegiados de seguridade social (art. 194, Parágrafo Único, VII); participação da população, por meio de organizações representativas, na formulação das políticas públicas e no controle das ações de assistência social (art. 204, II); gestão democrática do ensino público como princípio norteador da educação (art. 206, VII); participação da comunidade na promoção e proteção do patrimônio cultural brasileiro (art. $216, \S 1^{\circ}$ ); participação em audiências públicas, entre diversos outros ${ }^{78}$.

\footnotetext{
concepção hegemônica da democracia teorizou a questão da nova gramática de inclusão social como excesso de demandas", p. 60.

${ }^{77}$ CANOTILHO, J. J. Gomes. Op. Cit., p. 289.

78 CARDOSO, Rodrigo Mendes. Iniciativa Popular Legislativa da Assembleia Nacional Constituinte ao Regime da Constituição de 1988: um balanço. Rio de Janeiro. 2010. Dissertação (Mestrado) - Departamento de Direito da PUC-Rio, p. 33-34.
} 
Como é possível constatar a partir da análise dos exemplos elencados, o Constituinte idealizou um regime democrático amplamente participativo, em que a democracia seja incorporada nos hábitos do cotidiano, em qualquer tomada de decisão no qual o cidadão seja direta ou indiretamente afetado ou seja interessado - interessado não na concepção puramente subjetiva do termo, mas interessado enquanto integrante de uma coletividade e consciente disso. Desta feita, como acentua SILVA, democracia não é apenas forma de governo, mas muito mais do que isso, "é um processo de convivência, primeiramente para denotar sua historicidade, depois para realçar que, além de ser uma relação de poder político, é também um modo de vida, em que, no relacionamento interpessoal, há de verificar-se o respeito e a tolerância entre os conviventes"79.

Assim, assentado o princípio participativo no bojo da Constituição da 1988, qualquer forma de participação que dependa única e exclusivamente de eleição não realiza a democracia participativa no sentido atual da expressão, caracterizando-se esta pela participação direta e pessoal da cidadania na formação dos atos de governo ${ }^{80}$. Para tanto, as primeiras manifestações da democracia participativa consistiram nos institutos de democracia semidireta, na definição de José Afonso, que combinam instituições de participação direta com instituições de participação indireta, tais como: (i) iniciativa popular; (ii) plebiscito; (iii) referendo popular e (iv) ação popular. Vejamos, cada uma, em linhas gerais.

\subsubsection{Iniciativa Popular}

A iniciativa popular de lei tem seu fulcro constitucional no art. 14, III, e admite que o povo apresente projetos de lei ao Poder Legislativo, desde que subscritos por, no mínimo, um por cento do eleitorado nacional, distribuído pelo menos por cinco Estados, com não menos de três décimos por cento dos

\footnotetext{
${ }^{79}$ SILVA, José Afonso. Curso de Direito Constitucional Positivo, op. cit., p. 126.

${ }^{80}$ Ibid. p. 141.
} 
eleitores de cada um deles, conforme redação do art. $61, \S 2^{\circ}$, da CRFB/88. Portanto, a iniciativa popular caracteriza-se como uma forma direta de exercício do poder que emana do povo (art. $1^{\circ}$, Parágrafo Único), sem o intermédio de representantes, através de apresentação de projeto de lei que deflagra o processo legislativo de formação das leis ${ }^{81}$. Importante salientar que o projeto de lei de iniciativa popular somente diz respeito à iniciativa geral a que corresponde o caput do art. 60, não sendo lícito versar sobre matérias reservadas à iniciativa privativa de outros órgãos ou autoridades. Também não é cabível a iniciativa popular de Proposta de Emenda à Constituição, já que não há previsão expressa na Carta Política de 1988 que vislumbre essa possibilidade, o que, inclusive, é alvo de críticas da doutrina constitucionalista, vez que, parece incompatível com a ideia de soberania popular retirar dos cidadãos a legitimidade para apresentar proposta que vise a alterar a norma suprema da República.

Na prática, o rigorismo procedimental e numérico, num país populoso e com as discrepâncias regionais federativas como o Brasil, para a apresentação da iniciativa popular de leis, parece transformar este instrumento num "instituto meramente decorativo" 82 .

\subsubsection{Plebiscito e Referendo Popular}

O plebiscito e o referendo estão previstos, respectivamente, nos incisos I e II do art. 14 da CRFB/88. Ambos são semelhantes instrumentos de consulta popular pelo Poder Legislativo que, porém, diferem quanto ao momento de sua utilização. O plebiscito visa a decidir previamente uma questão política ou institucional, antes de sua formulação legislativa, ao passo que o referendo versa sobre aprovação de textos de projetos de lei ou emenda constitucional, já aprovados. Em outras palavras, o plebiscito

\footnotetext{
${ }^{81}$ LENZA, Pedro. Direito Constitucional Esquematizado. 16a ed. São Paulo: Saraiva, 2012, p. 553.

${ }^{82}$ CARDOSO, Rodrigo Mendes. Op. Cit., p. 36-37.
} 
autoriza a formulação da medida requerida, enquanto o referendo ratifica (confirma) ou rejeita o projeto aprovado. ${ }^{83}$

O plebiscito e o referendo podem ser utilizados pelo Congresso Nacional nos casos que este decidir ser conveniente, conforme art. 49, XV da Constituição, sendo os critérios e requisitos para o seu exercício regulados pela Lei 9.709/98. No entanto, a própria Constituição estabelece a obrigatoriedade de plebiscito, por exemplo, em casos específicos, como para a formação e desmembramento de novos Estados ou Municípios (art. 18, §§ $3^{\mathrm{o}}$ e $\left.4^{\mathrm{o}}\right)$.

\subsubsection{Ação Popular}

Como destaca Pedro Lenza, assim como o voto, a iniciativa popular, o plebiscito e o referendo, a ação popular, corroborando o preceituado no art. $1^{\circ}$, Parágrafo Único, da CRFB/88, constitui importante instrumento de democracia direta e participação política. Busca-se a proteção da res publica, ou, utilizando uma nomenclatura mais atualizada, tem por escopo a proteção dos interesses difusos ${ }^{84}$, como assevera José Afonso da Silva:

\footnotetext{
"Trata-se de um remédio constitucional pelo qual qualquer cidadão fica investido de legitimidade para o exercício de um poder de natureza essencialmente política, e constitui manifestação direta da soberania popular consubstanciada no art. $1^{\circ}$, parágrafo único, da Constituição: todo poder emana do povo, que o exerce por meio de seus representantes eleitos ou diretamente. Sob esse aspecto é uma garantia constitucional política. Revela-se como uma forma de participação do cidadão na vida pública, no exercício de uma função que lhe pertence primariamente." ${ }^{, 5}$
}

Visto que somente quem pode mover a ação popular é o cidadão, ela põe em prática o ideal democrático e a participação através do processo. $\mathrm{O}$ processo coletivo busca responder as demandas sociais relativas à tutela jurisdicional de direitos metaindividuais de uma sociedade pluralista e considerando a democracia deliberativa, ou seja, o processo como

\footnotetext{
${ }^{83}$ SILVA, José Afonso. Curso de Direito Constitucional Positivo, op. cit., p. 142.

${ }^{84}$ LENZA, Pedro. Op. Cit., p. 1059.

${ }^{85}$ SILVA, José Afonso. Curso de Direito Constitucional Positivo, op. cit., p. 463.
} 
instrumento de defesa social levando-se em conta o princípio da inafastabilidade da jurisdição. Há, portanto, o interesse público nas ações de natureza coletivas. Interesse público no sentido da relevância social do objeto tutelado. Nas palavras de Hely Lopes Meirelles, a ação popular é "um instrumento de defesa dos interesses da coletividade, utilizável por qualquer de seus membros. Por ela não se amparam direitos individuais próprios, mas, sim, interesses da comunidade. $\mathrm{O}$ beneficiário direto e imediato desta ação não é o autor; é o povo, titular do direito subjetivo ao governo honesto. $\mathrm{O}$ cidadão a promove em nome da coletividade, no uso de uma prerrogativa cívica que a Constituição da República lhe outorga" ${ }^{\text {" }}$.

\subsubsection{Participação Popular Não Institucionalizada}

Feitas essas considerações, pode-se concluir que os constituintes optaram por um modelo representativo, porém com temperos significativos de princípios e institutos de participação direta ${ }^{87}$ dos cidadãos no processo decisório governamental e, ao incorporar preceitos de justiça social e pluralismo, a Constituição de 1988 institui uma democracia social, participativa e pluralista. ${ }^{88}$

É preciso salientar, contudo, na esteira de José Afonso da Silva ao frisar que, sendo a democracia mais que um regime, mas sobretudo uma forma de vida, o processo de construção democrática da sociedade não é possível sem os meios de manifestação da soberania popular para além do direito posto, ou seja, das formas não institucionalizadas de participação ${ }^{89}$. Estas, por seu

\footnotetext{
${ }^{86}$ MEIRELLES, Hely Lopes et al.. Mandado de Segurança e Ações Constitucionais. $36^{\mathrm{a}}$ ed. São Paulo: Malheiros, 2014, p. 179.

87 Bobbio ressalta que "democracia representativa e democracia direta não são dois sistemas alternativos (no sentido de que onde existe uma não pode existir a outra), mas são dois sistemas que se podem integrar reciprocamente. Com a fórmula sintética, pode-se dizer que num sistema de democracia integral as duas formas de democracia são ambas necessárias mas não são, consideradas em si mesmas, suficientes", op. cit., p. 65.

${ }^{88}$ SILVA, José Afonso. Curso de Direito Constitucional Positivo, op. cit., p. 145-146.

${ }^{89}$ Nas palavras de Samantha Chantal Dobrowolski, “[...] adquire sentida importância, para a sobrevivência e ampliação da democracia nas sociedades complexas, a adoção de canais de participação que, além dos mecanismos jurídicos, de caráter eleitoral ou representativo, incluam
} 
turno, traduzem-se genuinamente, sob a ótica negriana, nas alternativas do Poder Constituinte ante as limitações impostas pela sua própria juridicização. A participação não institucionalizada - revelada nas ideias vitais de insurgência ${ }^{90}$, de desobediência civil $^{91}$, nos protestos e grandes manifestações de rua - materializa-se na potência despertada pelas lutas populares, configuradas na "multiplicidade das singularidades que se liberam e se manifestam",92.

Esta potência da multidão pôde, por exemplo, ser recentemente testemunhada no Brasil - e mais persistentemente no Rio de Janeiro - nas grandes manifestações que se desencadearam em meados de 2013. O período apelidado como as "Jornadas de Junho", levou milhões de pessoas às ruas da maioria das capitais do país. O movimento, com pautas absolutamente difusas teve seu estopim, como se sabe, no aumento das passagens de ônibus, mas gradualmente foi ganhando corpo e novos adeptos à medida que a escandalosa e desmedida repressão policial tornava-se explícita - expressão de palavras de ordem como: "Não é só pelos 20 centavos" ou "Por uma vida sem catracas". Assim, como precisamente alude o professor Adriano Pilatti, "[o]s levantes da multidão estão a demonstrar, desde junho, o que pode o poder constituinte quando o verbo se faz carne, quando os(as) meninos(as) 'desembestam', quando os risos denunciam os podres poderes constituídos que nada podem sem a desrazão das armas, quando a vida explode produtiva e criativamente em velozes composições e recomposições de potência horizontalmente articuladas"93.

outras possibilidades, inclusive de cunho informal, voltadas a deflagrar contínuos processos sociais, institucionais ou não, visando à constante atualização da Constituição e à legitimação de sua concretização em sede judicial", op. cit., p. 305.

${ }^{90} \mathrm{~A}$ respeito das nuances e formas que a insurgência pode tomar, o estudo de James Holston acerca da cidadania brasileira e a luta por direitos como moradia e infraestrutura urbana na periferia de São Paulo, Cidadania Insurgente: disjunções da democracia e da modernidade no Brasil. Tradução de Claudio Carina. São Paulo: Companhia das Letras, 2013.

${ }^{91}$ Sobre o tema, o clássico de Henry David Thoreau, Desobediência Civil \& outros escritos. Tradução de Alex Marins. São Paulo: Martin Claret, 2001.

${ }^{92}$ PILATTI, Adriano; COCCO, Giuseppe. A Persistência da Democracia Absoluta, in NEGRI, $O$ Poder Constituinte, op. cit., Xxx.

${ }^{93}$ Ibid. 
Ainda sob a pressão desse contexto, em tentativa de resposta à voz das ruas, a Presidência da República editou o Decreto $n^{\circ}$ 8.243/2014, que instituía a "Política Nacional de Participação Social - PNPS, com o objetivo de fortalecer e articular os mecanismos e as instâncias democráticas de diálogo e a atuação conjunta entre a administração pública federal e a sociedade civil" (art. $1^{\circ}$ ) e tinha como diretrizes gerais, segundo o art. $3^{\circ}$, o reconhecimento da participação social como direito do cidadão e expressão de sua autonomia (inciso I), complementariedade, transversalidade e integração entre mecanismos e instâncias da democracia representativa, participativa e direta (inciso II), além de estabelecer como objetivo a consolidação da participação social como método de governo (art. $4^{\circ}$, I). Para tanto, instituía organicamente um sistema de participação coordenado pela Secretaria-Geral da Presidência da República (art. $7^{\circ}$ ). Como era de se esperar, houve enorme resistência e críticas de membros do Congresso Nacional, culminando na sustação do referido decreto presidencial, sob o fundamento de que o mesmo exorbitava o seu poder regulamentar e invadia a esfera de competência legislativa do Parlamento (art. 49, V, da CRFB/88). A previsibilidade de tal ação apenas reafirma a dificuldade de se transcender o modelo puramente "representativo" que vigora na práxis brasileira, dominada por uma elite política que possui aversão histórica à simples ideia de um suposto aprofundamento da democracia, de integração do povo na tomada de decisões, de superação substancial do status quo das relações de poder sócio-políticas. Ainda assim, "Junho de 2013” ficará marcado como o momento do despertar de um longo período de dormência do povo, da multidão, da potência constituinte, ou como queira se denominar tal energia, como bem ressalta PILATTI, novamente, acerca da expressão daquele momento:

“[...] no ano em que nos reencontramos nas ruas e ousamos lutar, no ano das maravilhas e dos pesadelos, das imensas alegrias e das doídas dores... o ano em que corremos perigo, o ano em que caminhamos contra o vento e corremos contra a fumaça... o ano das galeras intrépidas, o ano dos patifes... mil sonhos floresceram, mil debates instigaram, mil abraços religaram... cada manifestante um cartaz, cada cartaz um desejo, o verbo que se fez carne, o sal da terra ... os dias promissores 
e frenéticos, as noites belas e horrendas, os mascarados, os desmascarados e os descarados... os amigos e as amigas de todas horas, todos os irmãos e irmãs que a rua nos deu... o ano que não vai acabar, o ano em que ninguém voltou da rua do mesmo jeito, o ano em que nos comprometemos amorosamente com o futuro que quase chegamos a tocar com as pontas dos dedos... havemos de alcançá-lo". 


\section{CAPÍTULO 2}

\section{DA JURISDIÇÃO CONSTITUCIONAL}

\subsection{A Força Normativa da Constituição}

Historicamente, o fato de existir um documento chamado Constituição nem sempre significou, para a estrutura jurídica do Estado, o que o atual constitucionalismo confere a este mesmo documento. Ao menos para o modelo europeu, no mundo pós-Revolução Francesa vigorava a ideia de centralidade da lei e a supremacia do Parlamento, não passando a Constituição de uma "carta de intenções" para a atuação dos Poderes Públicos ou, nas palavras de Ferdinand Lassalle, de um mero pedaço do papel, sem força normativa para produzir efeitos no âmbito das relações fáticas. ${ }^{94}$ Predominava, em vista disso, a concepção de que as questões constitucionais não consistiam em questões jurídicas, mas sim questões políticas e, portanto, estariam submetidas e condicionadas pelas relações de poder dominantes na respectiva sociedade, naquele respectivo tempo. Neste sentido, de acordo com HESSE,

[...] a concepção da força determinante das relações fáticas significa o seguinte: a condição de eficácia da Constituição jurídica, isto é, a coincidência de realidade e norma, constitui apenas um limite hipotético extremo. É que, entre a norma fundamentalmente estática e racional e a realidade fluída e irracional, existe uma tensão necessária e imanente que não se deixa eliminar. Para essa concepção do Direito Constitucional, está configurada permanentemente uma situação de conflito: a Constituição jurídica, no que tem de fundamental, isto é, nas disposições não propriamente de índole técnica, sucumbe cotidianamente em face da Constituição real. A ideia de um efeito determinante exclusivo da Constituição real não significa outra coisa senão a própria negação da Constituição jurídica. ${ }^{95}$

\footnotetext{
${ }^{94}$ HESSE, Konrad. A Força Normativa da Constituição. Tradução de Gilmar Ferreira Mendes. Porto Alegre: Sergio Antonio Fabris Editor, 1991.

${ }^{95}$ HESSE, Konrad. Op. Cit., p. 10-11.
} 
No entanto, como assinala BARROSO, uma das grandes mudanças de paradigma ocorridas ao longo do século $\mathrm{XX}$ foi a atribuição à norma constitucional do status de norma jurídica ${ }^{96}$. Ou seja, passou a ser mitigada a ideia de que a Constituição real - aquela ditada exclusivamente pelas relações fáticas e pelos fatores reais de poder, segundo Lassalle - sobressaíase sempre sobre a Constituição jurídica - mero pedaço de papel -, a partir do reconhecimento de que o "documento-Constituição" adquire força normativa na medida em que logra realizar essa pretensão de eficácia ${ }^{97}$. Isto não significa dizer que a norma constitucional tenha existência autônoma em face da realidade, mas pelo contrário, que a constatação de sua vigência se verifica exatamente pelo condicionamento recíproco existente entre a Constituição jurídica e a realidade político-social. Noutras palavras, a "Constituição não configura, portanto, apenas expressão de um ser, mas também de um dever ser; ela significa mais do que simples reflexo das condições fáticas de sua vigência, particularmente as forças sociais e políticas. Graças à pretensão de eficácia, a Constituição procura imprimir ordem e conformação à realidade política e social. Determinada pela realidade social e, ao mesmo tempo, determinante em relação a ela, não se pode definir como fundamental nem a pura normatividade, nem a simples eficácia das condições sócio-políticas e econômicas". 98

Sob este aspecto, a dimensão política da Constituição não exclui o seu caráter de norma jurídica, dotada de força ativa, estando ela inserida na

\footnotetext{
96 "Desse reconhecimento de caráter jurídico às normas constitucionais resultam consequências especialmente relevantes, dentre as quais se podem destacar: a) a Constituição tem aplicabilidade direta e imediata às situações que contempla, inclusive e notadamente as referentes à proteção e promoção dos direitos fundamentais. Isso significa que as normas constitucionais passam a ter um papel decisivo na postulação de direitos e na fundamentação de decisões judiciais; b) a Constituição funciona como parâmetro de validade de todas as demais normas jurídicas do sistema, que não deverão ser aplicadas quando forem com ela incompatíveis. A maior parte das democracias ocidentais possui supremas cortes ou tribunais constitucionais que exercem o poder de declarar leis e atos normativos inconstitucionais; c) os valores e fins previstos na Constituição devem orientar o intérprete e o aplicador do Direito no momento de determinar o sentido e o alcance de todas as normas jurídicas infraconstitucionais, pautando a argumentação jurídica a ser desenvolvida", BARROSO, Luís Roberto, op. cit., p. 232.

${ }^{97}$ HESSE, Konrad. Op. Cit., p. 16.

${ }^{98}$ Ibid. p. 15.
} 
interface entre esses dois domínios diversos, porém intercomunicantes, realizando a travessia entre o fato político e a ordem jurídica, entre o Poder Constituinte e o poder constituído ${ }^{99}$. Contudo, para que essa Carta Política tenha, de fato, força normativa, é preciso que se faça presente socialmente o que Konrad Hesse denominou vontade de Constituição. Segundo este autor, essa vontade de Constituição baseia-se, essencialmente,

\begin{abstract}
na compreensão da necessidade e do valor de uma ordem normativa inquebrantável, que proteja o Estado contra o arbítrio desmedido e disforme. Reside, igualmente, na compreensão de que essa ordem constituída é mais do que uma ordem legitimada pelos fatos (e que, por isso, necessita de estar em constante processo de legitimação). Assenta-se também na consciência de que, ao contrário do que se dá com a lei do pensamento, essa ordem não logra ser eficaz sem o concurso da vontade humana. Essa ordem adquire e mantém sua vigência através de atos de vontade. Essa vontade tem consequência porque a vida do Estado, tal como a vida humana, não está abandonada à ação surda de forças aparentemente inelutáveis. Ao contrário, todos nós estamos permanentemente convocados a dar conformação à vida do Estado, assumindo e resolvendo as tarefas por ele colocados. ${ }^{100}$
\end{abstract}

Nesta linha, quanto mais intensa for a vontade de Constituição, menos significativas hão de ser as restrições e os limites impostos à normatividade da Constituição ${ }^{101}$. Não obstante, salienta HESSE que a verdadeira prova de força da efetividade da Carta Magna somente pode ser observada em "tempos difíceis", de crise, ou de momentos sensíveis à atuação do Estado, razão pela qual ela deve também prever mecanismos de exceções da sua própria sistemática normativa diante dessas situações de emergência ou de estado de necessidade ${ }^{102}$ se almeja preservar a sua força normativa, visto que, dada a

\footnotetext{
${ }^{99}$ BARROSO, Luís Roberto. Op. Cit., p. 234.

${ }^{100}$ HESSE, Konrad. Op. Cit., p. 19-20.

${ }^{101}$ Ibid. p. 24. Sem embargo, Luís Roberto Barroso assevera que a "efetividade da Constituição há de assentar-se sobre alguns pressupostos indispensáveis. Como foi referido, é preciso que haja, da parte do constituinte, senso de realidade, para que não pretenda normatizar o inalcançável, o que seja materialmente impossível em dado momento e lugar. [...] [I]mpõe-se ao Poder Público vontade política, a concreta determinação de tornar realidade os comandos constitucionais. E, por fim, é indispensável o consciente exercício de cidadania, mediante a exigência, por via de articulação política e de medidas judiciais, da realização dos valores objetivos e dos direitos subjetivos constitucionais", op. cit., p. 256.

$102 \mathrm{Na}$ Constituição de 1988, por exemplo, temos hipóteses correspondentes a essas situações emergenciais, como a possibilidade da declaração de Estado de Defesa (art. 136) ou de Estado de Sítio (art. 137 e seguintes), que são verdadeiros cenários políticos de exceção, onde a própria Constituição admite temporariamente a suspensão de determinados direitos e garantias fundamentais devido à excepcionalidade das circunstâncias.
} 
gravidade de tais cenários, uma Constituição não flexível em relação a isso certamente sucumbiria perante as circunstâncias fáticas. Isto denota também que não só as possibilidades, mas também os limites da força normativa da Constituição resultam da correlação entre o "ser" e o “dever ser".

Essa tensão permanente entre norma e realidade apenas confirma que a Constituição não está desvinculada da realidade histórica concreta do seu tempo, porém, tampouco ela se reduz a uma mera expressão condicionada das circunstâncias. Em decorrência do elemento normativo, ela também ordena e conforma a realidade política e social de modo que, em caso de eventual conflito, a Constituição não deve ser considerada, necessariamente, a parte mais fraca. Ao contrário, como sustenta o renomado jurista germânico, existem pressupostos realizáveis que, mesmo em caso de confronto, permitem assegurar a força normativa da Constituição. ${ }^{103}$ Desta feita,

[a] concretização plena da força normativa constitui meta a ser almejada pela Ciência do Direito Constitucional. Ela cumpre seu mister de forma adequada não quando procura demonstrar que as questões constitucionais são questões de poder, mas quando envida esforços para evitar que elas se convertam em questões de poder (Machtfragen).

Em outros termos, o Direito Constitucional deve explicitar as condições sob as quais as normas constitucionais podem adquirir a maior eficácia possível, propiciando, assim, o desenvolvimento da dogmática e da interpretação constitucional. Portanto, compete ao Direito Constitucional realçar, despertar e preservar a vontade de Constituição (Wille zur Verfassung), que, indubitavelmente, constitui a maior garantia de sua formação normativa. ${ }^{104}$

Como se vê, a Constituição normativa não é mero conceito de ser; é um conceito de dever ser. Nas palavras de CANOTILHO, pressupõe uma ideia de relação entre um texto e um conteúdo normativo específico, ou seja: “(1) deve formar um corpo de regras jurídicas vinculativas do 'corpo político' e estabelecedoras de limites jurídicos ao poder, mesmo ao poder soberano (antidespotismo, antiabsolutismo); (2) esse corpo de regras vinculativas do

\footnotetext{
${ }^{103}$ HESSE, Konrad. Op. Cit., p. 25.

${ }^{104}$ Ibid. p. 27.
} 
corpo político deve ser informado por princípios materiais fundamentais, como o princípio da separação de poderes, a distinção entre poder constituinte e poderes constituídos, a garantia de direitos e liberdades, a exigência de um governo representativo, o controlo político e/ou judicial do poder". 105

Feitas essas considerações, resta realçar que esse movimento pela normatividade plena da Constituição, dentre tantos fenômenos resultantes, ensejou um de particular importância para a contemporânea configuração político-institucional, sobretudo no Brasil: a ascensão do Poder Judiciário, dando-lhe um papel mais destacado na concretização dos valores e dos direitos constitucionais. Esta grande mudança decorre do fato de que, como já abordado, enquanto a Constituição era vista como mero documento político sem força normativa, a realização do seu conteúdo ficava invariavelmente condicionada à liberdade de conformação do legislador ou à discricionariedade do administrador, não se conferindo ao Judiciário atribuição relevante na efetivação de matéria constitucional. Todavia, como aborda BARROSO,

[u]ma vez investida na condição de norma jurídica, a norma constitucional passou a desfrutar dos atributos essenciais do gênero, dentre os quais a imperatividade. Não é próprio de uma norma jurídica sugerir, recomendar, aconselhar, alvitrar. Normas jurídicas e, ipso facto, normas constitucionais contêm comandos, mandamentos, ordens, dotados de força jurídica, e não apenas moral. Logo, sua inobservância há de deflagrar um mecanismo próprio de coação, de cumprimento forçado, apto a garantir-lhes a imperatividade, inclusive pelo estabelecimento das consequências da insubmissão. É bem de ver, nesse domínio, que as normas constitucionais são não apenas normas jurídicas, como têm também um caráter hierarquicamente superior, não obstante a paradoxal equivocidade que longamente campeou nessa matéria, nelas vislumbrando prescrições desprovidas de sanção, mero ideário sem eficácia jurídica. ${ }^{106}$

Diante disso, não apenas a força normativa, mas sobretudo o patamar hierárquico da Constituição conferiu-lhe posição de centralidade na sistemática do ordenamento jurídico e na Ciência do Direito, motivando a

\footnotetext{
${ }^{105}$ CANOTILHO, J. J. Gomes. Op. Cit., p. 1130.
}

${ }^{106}$ BARROSO, Luís Roberto. Op. Cit., p. 253-254. 
necessidade de meios e procedimentos de controle, em geral exercidos no âmbito do Poder Judiciário, que assegurassem a juridicidade, e principalmente, a supremacia das normas constitucionais. No contexto estudado por HESSE, como ele mesmo menciona, o "significado superior da Constituição normativa manifesta-se, finalmente, na quase ilimitada competência das Cortes Constitucionais - princípio até então desconhecido -, que estão autorizadas, com base em parâmetros jurídicos, a proferir a última palavra sobre os conflitos constitucionais, mesmo sobre questões fundamentais da vida do Estado" ${ }^{107}$. Isto nos remete ao próximo tópico, ao qual se buscará desenvolver o tema relativo a guarda da Constituição, e a que atores e instituições são conferidos tal atribuição.

\subsection{O guardião da Constituição e a doutrina de Hans Kelsen}

Diante das ponderações até aqui realizadas, vê-se que efetivamente se consolida o Estado constitucional de direito, sobretudo na Europa continental, a partir de meados do século XX. Neste ínterim, com a compreensão da Constituição como norma jurídica, a ideia dominante, que vigorava até então, da centralidade da lei e da supremacia do Parlamento vai sendo substituída pela nova concepção de centralidade e supremacia da Constituição - sendo esta entendida como a base e fundamento de validade de todo o ordenamento jurídico, que não somente disciplina o modo de produção das leis e atos normativos, como estabelece determinados limites para o seu conteúdo, além de impor deveres de atuação ao Estado. ${ }^{108}$ Sobre esse tema, a clássica doutrina de Hans Kelsen mostra-se sempre pertinente:

\footnotetext{
${ }^{107}$ HESSE, Konrad. Op. Cit., p. 28.

108 BARROSO, Luís Roberto. Op. Cit., p. 436. No mesmo sentido Kelsen, em extensa nota de rodapé, afirma: "A Constituição interessa como norma que está acima da legislação porque define o procedimento legislativo, e em certa medida também o conteúdo das leis (a ser emanado com base na Constituição); do mesmo modo que a legislação está acima da assim-chamada execução (jurisdição, administração), eis que regula a formação e - em medida bastante ampla - o conteúdo dos respectivos atos", Quem deve ser o guardião da Constituição?, in Jurisdição Constitucional. $13^{\mathrm{a}}$ ed. São Paulo: WMF Martins Fontes, 2013, p. 261.
} 


\begin{abstract}
"Através das múltiplas transformações por que passou, a noção de Constituição conservou um núcleo permanente: a ideia de um princípio supremo determinando a ordem estatal inteira e a essência da comunidade constituída por essa ordem. Como quer que se defina a Constituição, ela é sempre o fundamento do Estado, a base da ordem jurídica que se quer apreender. O que se entende antes de mais nada e desde sempre por Constituição - e, sob esse aspecto, tal noção coincide com a de forma do Estado - é um princípio em que se exprime juridicamente o equilíbrio das forças políticas no momento considerado, é a norma que rege a elaboração das leis, das normas gerais para cuja execução se exerce a atividade dos organismos estatais, dos tribunais e das autoridades administrativas. Essa regra para a criação das normas jurídicas essenciais do Estado, a determinação dos órgãos e do procedimento da legislação, forma a Constituição no sentido próprio, original e estrito da palavra. Ela é a base indispensável das normas jurídicas que regem a conduta recíproca dos membros da coletividade estatal, assim como das que determinam os órgãos necessários para aplica-las e impô-las, e a maneira como devem proceder, isto é, em suma, o fundamento da ordem estatal"109
\end{abstract}

Desta feita, como já foi largamente demonstrado, a força normativa da Constituição pressupõe que seu conteúdo seja obrigatório juridicamente, assim como sua superioridade hierárquica só pode ser garantida mediante a existência de mecanismos de controle da regularidade - ou conformidade dos demais atos normativos em relação a ela. De fato, assenta KELSEN que é indispensável para a verdadeira garantia da Constituição a possibilidade da anulação dos atos inconstitucionais ${ }^{110}$, se configurando insuficiente, ou mesmo inútil, a mera previsão de uma sanção direta ao órgão ou agente que promulgou o ato inconstitucional, porquanto tal provimento, por si só, não é capaz de retirar a norma irregular do ordenamento jurídico. Seguindo esta lógica, o reconhecimento da supremacia da Constituição e de sua força vinculante em relação aos Poderes Públicos torna inevitável a discussão sobre as formas e os modos de defesa da mesma, e sobre a necessidade de um controle de constitucionalidade dos atos do Poder Público, especialmente das leis e atos normativos. ${ }^{111}$ Consequentemente surge, quase de forma intuitiva, a questão essencial relativa ao(s) órgão(s) ou instituição(ões) do Estado que seria(m) mais propriamente adequado(s) para exercer este

\footnotetext{
${ }^{109}$ KELSEN, Hans. A Garantia Jurisdicional da Constituição, in Jurisdição Constitucional. $13^{\mathrm{a}}$ ed. São Paulo: WMF Martins Fontes, 2013, p. 130-131.

110 Ibid. p. 149.

${ }^{111}$ MENDES, Gilmar. Op. Cit., p. 1097.
} 
controle de constitucionalidade. Quem deveria ser o guardião da Constituição?

Como é fato notório, em breve retrospecto, a doutrina constitucionalista costuma atribuir ao célebre caso Marbury v. Madison, em 1803, nos Estados Unidos, como o marco histórico que impulsionou a jurisdição constitucional. O caso foi a primeira decisão na qual a Suprema Corte norte-americana afirmou seu poder de exercer o controle de constitucionalidade, negando aplicação a leis que, de acordo com sua interpretação, fossem inconstitucionais. Importante assinalar ainda, segundo BARROSO, que a Constituição não conferia a ela ou a qualquer outro órgão judicial, de modo explícito, competência dessa natureza. Ao julgar o caso, a Corte procurou demonstrar que a atribuição decorreria logicamente do sistema. A argumentação desenvolvida por John Marshall, então Presidente daquela Corte (Chief Justice), “acerca da supremacia da Constituição, da necessidade do judicial review e da competência do Judiciário na matéria é tida como primorosa, embora não fosse pioneira nem original" ${ }^{112}$. Em linhas gerais, como salientado, Marshall expôs três grandes fundamentos que justificariam o controle judicial de constitucionalidade:

\begin{abstract}
"Em primeiro lugar, a supremacia da Constituição: 'Todos aqueles que elaboram constituições escritas encaram-na como lei fundamental e suprema da nação'. Em segundo lugar, e como consequência natural da premissa estabelecida, afirmou a nulidade da lei que contrarie a Constituição: 'Um ato do Poder Legislativo contrário à Constituição é nulo'. E, por fim, o ponto mais controvertido de sua decisão, ao afirmar que é o Poder Judiciário o intérprete final da Constituição: 'É enfaticamente da competência do Poder Judiciário dizer o Direito, o sentido das leis. Se a lei estiver em oposição à constituição a corte terá de determinar qual dessas normas conflitantes regerá a hipótese. E se a constituição é superior a qualquer ato ordinário emanado do
\end{abstract}

\footnotetext{
112 BARROSO, Luís Roberto. O Controle de Constitucionalidade no Direito Brasileiro. $6^{\mathrm{a}}$ ed. São Paulo: Saraiva, 2012, p. 27. Ressalta Barroso que, de fato, havia precedentes jurisprudenciais, ainda que não se equipare em importância, no âmbito de cortes federais inferiores e estaduais. E, no plano teórico, Alexander Hamilton, no Federalista n. 78, já havia exposto analiticamente a tese, já em 1788, conforme transcreve: "Nenhum ato contrário à Constituição pode ser válido. (...) A presunção natural, à falta de norma expressa, não pode ser a de que o próprio órgão legislativo seja juiz de seus poderes e que sua interpretação sobre eles vincula os outros Poderes. (...) É muito mais racional supor que os tribunais é que têm a missão de figurar como corpo intermediário entre o povo e o Legislativo, dentre outras razões, para assegurar que este último se contenha dentro dos poderes que lhe foram deferidos. A interpretação das leis é o campo próprio e peculiar dos tribunais. Aos juízes cabe determinar o sentido da Constituição e das leis emanadas do órgão legislativo. (...) Onde a vontade do Legislativo, declarada nas leis que edita, situar-se em oposição à vontade do povo, declarada na Constituição, os juízes devem curvar-se à última, e não à primeira”, apud, p. 28.
} 
legislativo, a constituição, e não o ato ordinário, deve reger o caso ao qual ambos se aplicam"113

Ressalte-se que a construção teórica permite o controle de constitucionalidade por qualquer membro ou tribunal integrante do Poder Judiciário, não sendo atividade exclusiva da Suprema Corte, visto que tal entendimento decorre do exercício típico da jurisdição (do latim, juris, "direito", e dicere, "dizer", ou seja, a função típica de "dizer o direito”). Já que incumbe a todos os juízes a atribuição da aplicação do direito, e sendo a Constituição norma jurídica, compete a qualquer membro do Poder Judiciário a função de interpretar tal aparato normativo e, fatalmente, exercer o controle de constitucionalidade das leis ou de qualquer outro ato estatal. Desta forma, diz-se que o modelo norte-americano é difuso e não concentrado, pois não é efetuado por um único órgão de controle. Observação relevante se faz no que se refere a essa quebra de paradigma causada pelo sistema da judicial review nos Estados Unidos, consagrando uma ruptura substancial com a tradição europeia - especificamente inglesa, no âmbito da common law -, a respeito da soberania do Parlamento ${ }^{114}$.

Aliás, como bem salienta KELSEN, de forma diversa se deu o desenvolvimento da tese da garantia da Constituição no contexto europeu, onde a instituição de um controle de constitucionalidade das leis pelo Poder Judiciário sofreu rigorosas objeções e forte resistência. Como já foi visto no tópico 1.1 deste trabalho, a ideologia da Revolução Francesa assentou, inicialmente, a soberania popular na própria noção de representação política parlamentar, estabelecendo "entre o corpo legislativo e as outras autoridades uma espécie de desigualdade que tinha uma causa profunda e que excluía qualquer possibilidade de uma separação verdadeira e substancial entre poder legislativo e poder constituinte. Enquanto o executivo e a autoridade judiciária exerciam suas atribuições na forma e com poderes de funcionários

${ }^{113}$ Ibid. p. 30.

${ }^{114}$ MENDES, Gilmar. Op. Cit., p. 1100. 
que agem a serviço da nação, a assembleia de deputados, concebida como o órgão que 'quer pela nação', se tornava a 'representação' mesma desta última e adquiria, a este título, a posse da soberania nacional com os poderes daí decorrentes" 115 .

Esta proeminência do Poder Legislativo em relação aos outros dois Poderes se justificaria, segundo a doutrina da Revolução, pois pressupunhase que o povo - ou a vontade dele - estaria tão presente na elaboração das leis pelo legislador ordinário quanto na Constituição elaborada por uma assembleia constituinte ${ }^{116}$. Concebendo-se as leis, portanto, como expressão pura e imediata da soberania popular seria naturalmente inconcebível, sob esta ótica, admitir-se qualquer tipo de controle ou restrição das mesmas pelo Judiciário, instituição, em tese, desprovido de legitimidade democrática para tanto $^{117}$. Esta teoria, nas palavras de KELSEN, reduz a questão da constitucionalidade das leis "substancialmente a uma questão de interpretação dos textos e dos princípios constitucionais, interpretação que tem por objeto preciso o de procurar e estabelecer a amplitude e o alcance das limitações postas pela Constituição ao poder do legislador" ${ }^{118}$. Sendo a atividade parlamentar considerada a própria manifestação da soberania popular, a interpretação que esta extraiu da Constituição ao elaborar o texto da lei é, segundo esta lógica, a interpretação mais qualificada

\footnotetext{
${ }^{115}$ Neste sentido, expõe ainda que era "como dizer que, no corpo legislativo, no momento da elaboração das leis, está presente o próprio povo ou a totalidade dos cidadãos. O que o legislador decidiu é decisão legislativa do povo, isto é, não de uma autoridade encarregada pelo povo, mas do próprio povo soberano. Abria-se desse modo um abismo jurídico entre o poder legislativo da assembleia dos deputados, que representa a nação, e as competências das outras autoridades, que só ocupam cargos como funcionários", KELSEN, Hans, A Garantia Jurisdicional da Constituição, op. cit., p. 200-201.

${ }^{116}$ Ibid. p. 204.

117 Ainda hoje, em alguns sistemas, percebe-se a tendência em se rechaçar o controle de constitucionalidade jurisdicional ao retirar da incumbência do Poder Judiciário a possibilidade de anular, ou de deixar de aplicar, normas sob a justificativa de desconformidade com a Constituição. Cogita-se, portanto, de "controle de constitucionalidade político, também chamado modelo francês, quando a atividade de controle de constitucionalidade é exercida por órgão político e não por órgão jurisdicional”, MENDES, Gilmar, op. cit., p. 1097. Nesta linha, completa Luís Roberto Barroso que "razões históricas e ideológicas levaram os franceses à desconfiança em relação ao poder dos juízes e dos tribunais, com a consequente adoção de um modelo rígido de separação de Poderes. Daí a rejeição à formula do controle judicial", O Controle de Constitucionalidade no Direito Brasileiro, op. cit., p. 64 .

${ }^{118}$ KELSEN, Hans, A Garantia Jurisdicional da Constituição, op. cit., p. 204.
} 
democraticamente e, portanto, inviolável por qualquer outro Poder. Volta-se assim, na prática, à supremacia do Parlamento. Tal concepção, no entanto, não prospera diante da crítica de KELSEN, ao observar que:

“[...] o corpo legislativo não pode ser confundido com o povo soberano: é uma
simples autoridade investida, não da soberania, mas de um poder, e no exercício das
suas funções age do mesmo modo derivado que os outros corpos ou autoridades
constituídas no exercício das suas respectivas funções. As leis que ele adota são, com
respeito à Constituição, apenas atos de poder subalterno, legítimos unicamente nos
limites em que seu conteúdo, obra de um órgão constituído, não está em contradição
com nenhuma das disposições superiores estabelecidas pelo soberano, isto é, pelo
povo, autor do ato constituinte. Nessas condições, é natural que os juízes - embora
sujeitos às leis ordinárias, na medida em que sua função consiste principalmente em
aplica-las - não possam e não devam aplicá-las a não ser depois de ter como certa
sua regularidade constitucional. De fato, diante da Constituição eles estão, quanto ao
exercício da sua função e segundo esse ponto de vista, em pé de igualdade com o
legislador, dado que este representa o povo de forma não-diferente da dos juízes". ${ }^{119}$

Deste modo, ele segue linha de argumentação semelhante à do juiz Marshall da Suprema Corte norte-americana em favor do controle de constitucionalidade das leis, não vislumbrando óbice que a mesma se dê no âmbito jurisdicional, mas pelo contrário, pressupondo a jurisdição constitucional como condição essencial para a garantia da Constituição, que somente será possível "se a anulação do ato irregular for pronunciada imediatamente por um órgão completamente diferente e independente daquele que produziu o ato irregular" ${ }^{20}$. Não obstante, KELSEN afasta-se do modelo difuso-concreto americano ao idealizar um órgão específico para desempenhar esta jurisdição: uma Corte Constitucional que exerceria um controle concentrado-abstrato de constitucionalidade. Este sistema de controle, como se sabe, ficou conhecido como modelo austríaco pois foi adotado pela primeira vez pela Constituição da Áustria de 1920 - e aperfeiçoado significativamente por via de emenda em 1929 -, e expressava as convicções doutrinárias de KELSEN que se alastrou nas décadas seguintes por grande parte da Europa continental.

\footnotetext{
${ }^{119}$ Ibid. p. 199.

${ }^{120}$ Ibid. p. 147.
} 
Explica BARROSO, com sua didática característica, que duas razões fático-jurídicas induziram ao desenvolvimento de um modelo alternativo nos países continentais europeus em relação ao método norte-americano: a) a inexistência de stare decisis ${ }^{121}$ em sistemas judiciais; b) a existência de magistratura de carreira para a composição dos tribunais ${ }^{122}$. Em outras palavras, diante da ausência de um sistema que garantisse minimamente uma uniformidade das decisões das instâncias judiciárias relativas ao controle de constitucionalidade, mostrou-se necessário, na visão de KELSEN, a criação de um órgão específico - um tribunal constitucional - para o desempenho dessa competência ${ }^{123}$. A partir dessa ideia de que as Cortes Constitucionais, por terem como atribuição precípua o juízo da constitucionalidade da lei em tese - ou seja, em abstrato -, e não em sede de um caso concreto, alguns juristas entendem que as mesmas não seriam dotadas de função judicial. Seu papel seria tão somente retirar uma norma considerada inconstitucional do ordenamento jurídico, operando, na concepção clássica kelseniana, como "legislador negativo". E justamente por não integrarem, a rigor, a estrutura do Poder Judiciário, remete-se ao segundo fundamento elencado por BARROSO: o tribunal constitucional não deveria ser composto por juízes de carreira, mas por pessoas com perfil mais próximo ao de "homens de

\footnotetext{
121 "Como se sabe, nos países que seguem a tradição do common law, em contraposição aos que se filiam à família romano-germânica, existe a figura do stare decisis. Esta expressão designa o fato de que, a despeito de exceções e atenuações, os julgados de um tribunal superior vinculam todos os órgãos judiciais inferiores no âmbito da mesma jurisdição. Disso resulta que a decisão proferida pela Suprema Corte é obrigatória para todos os juízes e tribunais. E, portanto, a declaração de inconstitucionalidade em um caso concreto traz como consequência a não aplicação daquela lei a qualquer outra situação, porque todos os tribunais estarão subordinados à tese jurídica estabelecida. De modo que a decisão, não obstante referir-se a um litígio específico, produz efeitos gerais, em face de todos (erga omnes)", BARROSO, Luís Roberto. O Controle de Constitucionalidade do Direito Brasileiro, op. cit., p. 70-71.

${ }^{122}$ Ibid. p. 70.

${ }^{123}$ Nota-se a preocupação, também, em salvaguardar a segurança jurídica que não seria garantida $a$ priori num sistema judicial ausente de um stare decisis: "A centralização do poder de examinar a regularidade das normas gerais certamente se justifica sob todos os aspectos. Mas se se decide confiar esse controle a uma autoridade única, torna-se possível abandonar a limitação da anulação ao caso concreto e adotar o sistema da anulação total, isto é, para todos os casos em que a norma deveria ter sido aplicada. É óbvio que um poder tão considerável só pode ser confiado a uma instância central suprema", KELSEN, Hans, A Garantia Jurisdicional da Constituição, op. cit., p. 145.
} 
Estado"124. Aqui, é notável ainda a presença da precaução teórica pautada na velha desconfiança europeia em se conferir ao Judiciário demasiado poder, ainda que se reconheça que a atividade da Corte Constitucional seja tipicamente jurisdicional. Assinala KELSEN, em texto crítico à tese de Carl Schmitt que vislumbra no chefe do Poder Executivo o "guardião" ideal da Constituição, as suas ponderações acerca da pertinência de uma Corte Constitucional:

\begin{abstract}
"Este funciona como um tribunal constitucional central na medida em que, num processo litigioso, deve decidir sobre a constitucionalidade de atos do Parlamento (especialmente leis) ou do governo (especialmente decretos) que tenham sido contestados, cassando tais atos em caso de sua inconstitucionalidade, e eventualmente julgando sobre a responsabilidade de certos órgãos colocados sob acusação. Pode-se certamente discutir sobre a conveniência de tal instituição, e ninguém afirmará que se trata de uma garantia absolutamente eficaz em qualquer circunstância. Mas de todos os pontos de vista segundo os quais se possa debater o problema jurídico-político de um tribunal constitucional central e estabelecer seus prós e contras, um ponto é de fato insignificante: o de se tal órgão seria um tribunal e sua função verdadeiramente jurisdicional. No plano da teoria do direito, essa é realmente uma questão de classificação muito importante; da sua solução, contudo, tanto em sentido afirmativo como negativo, nada resulta a favor ou contra que se confie a referida função a um órgão colegiado cujos membros, a ser nomeados de alguma maneira, tenham garantia a plena independência: uma independência em relação a governo e Parlamento e que chamamos judiciária, porque nas modernas Constituições costuma ser concedida aos tribunais (aliás, não apenas estes). Deduzir, a partir de um conceito qualquer de jurisdição, que a instituição aqui referida como tribunal constitucional seria impossível ou inconveniente, seria um caso típico daquela jurisprudência conceitual, que já pode ser considerada como superada hoje em dia." 125
\end{abstract}

Desta maneira, pode-se concluir que o guardião da Constituição idealizado por KELSEN seria um Tribunal Constitucional, neutro e independente em relação ao suposto antagonismo entre os outros Poderes, com a única função de realizar o controle de constitucionalidade das normas e atos infraconstitucionais de forma abstrata - pois analisa a lei em tese e desvinculada do caso concreto -, e concentrada - já que tal exercício é de sua competência exclusiva. Portanto, a diferença entre o tribunal constitucional e qualquer outro tribunal integrante do Poder Judiciário é que,

\footnotetext{
${ }^{124}$ BARROSO, Luís Roberto. O Controle de Constitucionalidade do Direito Brasileiro, op. cit., p. 71.

${ }^{125}$ KELSEN, Hans, Quem deve ser o guardião da Constituição? op. cit., p. 248.
} 
"embora sendo ambos aplicadores e produtores do direito, o segundo produz apenas normas individuais, enquanto o primeiro, ao aplicar a Constituição a um suporte fático de produção legislativa, obtendo assim uma anulação da lei inconstitucional, não produz, mas elimina uma norma geral, instituindo assim o actus contrarius correspondente à produção jurídica, ou seja, atuando - como formulei anteriormente - como legislador negativo" ${ }^{126}$.

\subsection{A legitimidade democrática da jurisdição constitucional e o papel do Supremo Tribunal Federal no desenho institucional brasileiro}

As Constituições contemporâneas, como destaca BARROSO, desempenham, de modo geral, dois grandes papéis: (i) o de condensar os valores políticos nucleares da sociedade, os consensos mínimos quanto a suas instituições e quanto aos direitos fundamentais nela consagrados; e (ii) o de disciplinar o processo político democrático, propiciando o governo da maioria, a participação da minoria e a alternância de poder ${ }^{127}$. Em suma, o grande papel de um Tribunal Constitucional - na forma idealizada de guarda da Constituição - nas sociedades modernas é proteger e promover os direitos fundamentais, além de resguardar as regras do jogo democrático ${ }^{128}$. Desta forma, pode-se dizer que o arranjo institucional que se mostrou hegemônico a partir do século XX, inclusive no Brasil, foi o que ficou denominado constitucionalismo democrático. Este, por seu turno, traduz a conjugação de duas construções políticas para produzir o modelo ideal contemporâneo: democracia, que significa soberania popular, governo do povo, vontade da

\footnotetext{
${ }^{126}$ Ibid. p. 263.

${ }^{127}$ BARROSO, Luís Roberto. Curso de Direito Constitucional Contemporâneo, op. cit., p. 447. ${ }^{128}$ Assim, segundo observa Gustavo Binenbojm, pode-se dizer que à Corte Constitucional cabe pronunciar a última palavra institucional no âmbito do Estado democrático de direito: "Realmente, como intérprete último da Constituição, compete-lhe ditar aos demais poderes os limites de sua autoridade, velando por que atuem pautados pelos procedimentos e dentro dos limites substanciais constitucionalmente previstos", A Nova Jurisdição Constitucional Brasileira. Legitimidade democrática e Instrumentos de realização. $4^{\mathrm{a}}$ ed. Rio de Janeiro: Renovar, 2014, p. 49.
} 
maioria; e constitucionalismo, que, por sua vez, abarca a ideia de poder limitado e respeito aos direitos fundamentais, abrigados, como regra geral, em uma Constituição escrita. ${ }^{129}$

Tradicionalmente, a partir de uma concepção de democracia representativa, costuma-se atribuir aos agentes públicos eleitos - no caso brasileiro, o chefe do Poder Executivo e os membros do Poder Legislativo a encarnação da soberania popular. Questiona-se, desta forma, sobre a legitimidade democrática de um Tribunal Constitucional, ou qualquer outro órgão do Poder Judiciário que tenha a incumbência de exercer a proteção da Constituição mediante o poder de anular, eventualmente, atos dos outros dois poderes. Dentre esses críticos encontra-se Carl Schmitt que, ao defender o chefe do Poder Executivo como o cargo mais adequado democraticamente para exercer a "guarda da Constituição", acaba por impelir KELSEN a contestá-lo através do exemplo da própria estrutura da Corte Constitucional austríaca:

"Por que um tribunal constitucional seria um guardião antidemocrático da Constituição, menos democrático que o chefe de Estado? O caráter democrático de um tribunal constitucional, não diferente daquele do chefe de Estado, só poderá depender do modo de sua nomeação e de sua posição jurídica. Caso se queira dar uma configuração democrática a esse tribunal, nada impede que o façamos ser eleito pelo povo, como o chefe de Estado, e que se dê a seus membros tão pouco quanto ao chefe de Estado a posição de funcionários de carreira; ainda que certamente pudesse permanecer a questão sobre se tal modo de criar e qualificar o órgão seria o mais conveniente, considerando-se a sua função. Tais ponderações, porém, valem também para o chefe de Estado. Seja como for, não é possível afirmar que um tribunal não possa ser estruturado de modo tão democrático quanto qualquer outro órgão. Quando Schmitt opina que: 'Do ponto de vista democrático dificilmente seria possível confiar tais funções a uma aristocracia da toga', tal objeção é liquidada simplesmente pelo fato de que um tribunal constitucional eleito pelo povo, ou apenas pelo parlamento - como, por exemplo, a Corte Constitucional austríaca nos moldes da Constituição de 1920 -, é tudo menos uma 'aristocracia de toga'. Mas segundo a exposição de Schmitt, um tribunal constitucional parece antidemocrático [...], eis que liga tal argumento diretamente à afirmação de que a instituição de um tribunal constitucional seria contrária ao princípio democrático; no âmbito da democracia parlamentar-plebiscitária do século XX - assim sustenta Schmitt - um tribunal constitucional não estaria, como na monarquia constitucional do século XIX, voltado 'contra um monarca, mas sim contra o Parlamento'.,"130

\footnotetext{
${ }^{129}$ BARROSO, Luís Roberto. Curso de Direito Constitucional Contemporâneo, op. cit., p. 475.

${ }^{130}$ KELSEN, Hans. Quem deve ser o guardião da Constituição?, op. cit., p. 291-292.
} 
Veja-se, no entanto, que o eminente jusfilósofo vienense restringe-se a buscar a explicação do caráter democrático da Corte através dos mecanismos de nomeação de seus membros, e menos a partir da natureza de sua atuação e de seu papel institucional no horizonte de um Estado Democrático de Direito. Porém, como já foi visto no tópico 1.3 deste trabalho, a soberania popular não se reflete unicamente na noção da representatividade majoritária, mas também - e principalmente, no contexto das sociedades complexas atuais - na constante interação social dialética de construção democrática ${ }^{131}$, que por sua vez, só pode ser assegurada se tiver como pressuposto a garantia dos direitos fundamentais. Claramente, o que se coloca no cerne do debate é justamente essa incessante tensão entre os instrumentos de vontade majoritária e a preservação de direitos sedimentados no texto constitucional que, mesmo em detrimento do arbítrio da maioria, devem ser resguardados. Como bem ressalta Gustavo Binenbojm, é "precisa a observação de Habermas [...] de que a crítica à jurisdição constitucional é conduzida quase sempre sob o prisma da distribuição de competência entre legislador democrático e justiça; e, nesta medida, ela é sempre uma disputa em torno do princípio da divisão de poderes. A assertiva soa quase tautológica: quanto mais ampla a atividade judicante da Corte Constitucional, menor o espaço de livre conformação do Legislativo. A calibragem exata dessa distribuição de poder é uma discussão teórica que permanece em aberto" ${ }^{132}$. De fato, continua o jurista, no limite desta tensão,

[...] o irrestrito poder da maioria poderia subverter as regras jurídicas que disciplinam o seu exercício e vulnerar o conteúdo essencial daqueles direitos; por outro lado, a cristalização de determinados princípios jurídicos, elevados à condição de paradigmas do Direito, poderia acarretar uma indesejável asfixia da vontade popular. O papel do constitucionalismo é o de harmonizar esses ideais até um "ponto ótimo"

\footnotetext{
${ }^{131}$ Nesta linha, Barroso, em Curso de Direito Constitucional Contemporâneo, op. cit., p. 477: “A legitimidade política não decorre apenas da representação por via eleitoral, que autoriza os parlamentares a tomarem decisões em nome do povo. Ao lado dos conceitos eleições e do princípio majoritário, a ideia de democracia deliberativa não só comporta como exige um outro componente: uma representação argumentativa ou discursiva. $\mathrm{O}$ constitucionalismo democrático se funda na institucionalização da razão e da correção moral. Isso significa que uma decisão da corte suprema, para ser inquestionavelmente legítima, deverá ser capaz de demonstrar: (i) a racionalidade e a justiça do seu argumento, bem como (ii) que ela corresponde a uma demanda social objetivamente demonstrável".

${ }^{132}$ BINENBOJM, Gustavo. Op. Cit., p. 93-94.
} 
de equilíbrio institucional e desenvolvimento da sociedade política, sendo tal ponto a medida de sucesso de uma Constituição". 133

Deste modo, ainda que a jurisdição constitucional não se mostre como um componente indispensável para todo e qualquer modelo de democracia como é prova cabal o sistema britânico, por exemplo -, ainda assim, ela tem se mostrado, de uma maneira hegemônica, útil e eficaz no amparo das regras do jogo democrático. Sob esta lógica, no âmbito de uma democracia constitucional, os direitos fundamentais devem ficar imunes à vontade das maiorias legislativas eventuais, uma vez que neles se reconhece o prérequisito necessário e essencial do processo democrático. Com efeito, a maioria democraticamente eleita não tem a prerrogativa de inviabilizar o próprio procedimento democrático. Aqui se situa o locus de atuação legítima da jurisdição constitucional: a proteção do sistema de direitos que possibilita, segundo a perspectiva habermasiana, a autonomia privada e pública dos cidadãos, condição da gênese democrática das leis. ${ }^{134}$ Desta forma, BARROSO observa na Corte Constitucional contemporânea a presença simultânea de duas características essenciais: o seu papel contramajoritário, quando em nome da Constituição, da proteção das regras do jogo democrático e dos direitos fundamentais, cabe a ela a atribuição de declarar a inconstitucionalidade das leis - e portanto, de decisões majoritárias tomadas pelo Legislativo - e de atos do Poder Executivo - cujo chefe foi eleito pela maioria absoluta dos cidadãos; e também o seu papel representativo, quando do atendimento, pelo Tribunal, de demandas sociais e de anseios políticos que não foram satisfeitos a tempo e a hora pela atuação legislativa. ${ }^{135}$ Interessante notar, no que se refere ao aspecto

\footnotetext{
133 Ibid. p. 48.

${ }^{134}$ Ibid. p. 112-113.

${ }^{135}$ BARROSO, Luís Roberto. Curso de Direito Constitucional Contemporâneo, op. cit., p. 476. Nesta linha, destaca ainda Samantha Chantal Dobrowolski sobre outra faceta representativa da Corte a partir do entendimento de Robert Alexy, "para quem o tribunal constitucional representa o 'povo' argumentativamente, enquanto o Legislativo detém a representação política. [...] Deste modo, o tribunal constitucional assume o papel de uma instância de reflexão do processo político e se o diálogo entre ele, a coletividade e o legislador logra estabilizar-se, pode-se considerar alcançada a
} 
contramajoritário da Corte, que KELSEN já salientava - em bela passagem

- a salutar relevância da jurisdição constitucional como instrumento de defesa das minorias políticas, razão pela qual entendemos ser apropriado transcrevê-la:

"Garantindo a elaboração constitucional das leis, e em particular sua constitucionalidade material, ela [a jurisdição constitucional] é meio de proteção eficaz da minoria contra os atropelos da maioria. A dominação desta só é suportável se for exercida de modo regular. A forma constitucional especial, que consiste de ordinário em que a reforma da Constituição depende de uma maioria qualificada, significa que certas questões fundamentais só podem ser solucionadas em acordo com a minoria: a maioria simples não tem, pelo menos em certas matérias, o direito de impor sua vontade à minoria. Somente uma lei inconstitucional, aprovada por maioria simples, poderia então invadir, contra a vontade da minoria, a esfera de seus interesses constitucionais garantidos. Toda minoria - de classe, nacional ou religiosa - cujos interesses são protegidos de uma maneira qualquer pela Constituição, tem pois um interesse eminente na constitucionalidade das leis. [...] Se virmos a essência da democracia não na onipotência da maioria, mas no compromisso constante entre os grupos representados no Parlamento pela maioria e pela minoria, e por conseguinte na paz social, a justiça constitucional aparecerá como um meio particularmente adequado à realização dessa ideia. A simples ameaça do pedido ao tribunal constitucional pode ser, nas mãos da minoria, um instrumento capaz de impedir que a maioria viole seus interesses constitucionalmente protegidos, e de se opor à ditadura da maioria, não menos perigosa para a paz social que a da minoria". 136

Esta qualidade contramajoritária, na defesa dos direitos de minorias políticas, pode ser vista especialmente na atuação recente do Supremo Tribunal Federal. Porém, antes, um breve histórico acerca da atividade institucional desse tribunal se mostra conveniente. Como se sabe, desde a primeira Constituição republicana de 1891 é adotado no Brasil uma jurisdição constitucional inspirada no modelo norte-americano, bem como a estruturação do STF nos moldes da Suprema Corte daquele país. Desta forma, vigorava exclusivamente um controle de constitucionalidade concreto-difuso e incidental. Obviamente a adaptação "à brasileira" apresentou-se capenga vez que, integrando-se à família romano-germânica,

institucionalização dos direitos humanos no Estado democrático de direito e reconciliados os direitos humanos e a soberania popular", op. cit., p. 309.

${ }^{136}$ KELSEN, Hans. A Garantia Jurisdicional da Constituição, op. cit., p. 181-182. Ainda sobre este tema, Gustavo Binenbojm, op. cit., p. 103: "[...] cabe à Corte Constitucional facilitar a representação das minorias, sustando leis que exibam caráter discriminatório e, como tal, representem risco para a higidez do sistema representativo. Nestes casos, a maioria política não merece confiança, pois seus interesses podem colocar em xeque a própria democracia". 
não aderiu o mesmo sistema de vinculação de precedentes e do já mencionado stare decisis. Em 1965, com a introdução da ação genérica de inconstitucionalidade, pela Emenda Constitucional $\mathrm{n}^{\mathbf{0}} 16$, inspirada no modelo austríaco de controle concreto-abstrato - em que pese a existência antecedente da chamada representação interventiva, criada pela Constituição de $1934^{137}$ - a ascensão política do STF, em razão do desempenho mais incisivo propiciado pelo novo instituto, foi inevitável. Porém o ápice institucional do Supremo Tribunal Federal mostra-se atualmente, sob a égide da Carta Política de 1988, onde o Pretório Excelso ganhou verdadeiras feições de Corte Constitucional, ainda que formalmente não o fosse nos moldes germânicos ${ }^{138}$. Desde então o Supremo decidiu causas emblemáticas e de grande repercussão, demonstrando inclusive posição de vanguarda política no resguardo dos direitos das minorias, muitas vezes sob forte pressão popular e midiática. Dentre estas causas, podem-se citar, a título de exemplo, as que diziam respeito a: políticas de ação afirmativa de acesso ao ensino superior (ADPF 186), reconhecimento da união estável homoafetiva (ADPF 132 e ADI 4277), pesquisas com células-tronco embrionárias (ADI 3510), interrupção de gestação de fetos anencefálicos (ADPF 54), entre outros.

Assim, é possível afirmar que, sobretudo a partir da redemocratização da segunda metade da década de 80, circunstâncias como a amplitude da Constituição de 1988, a combinação da jurisdição constitucional concentrada e difusa, bem como a constitucionalização do Direito deram lugar a um fenômeno muito visível no cenário brasileiro contemporâneo: a

\footnotetext{
${ }^{137}$ BARROSO, Luís Roberto. O Controle de Constitucionalidade do Direito Brasileiro, op. cit., p. 179.

${ }^{138}$ Ainda que o ordenamento constitucional brasileiro não tenha convertido o Supremo Tribunal Federal propriamente em Corte Constitucional, como anota Gisele Cittadino, "reduziu sua competência à matéria constitucional, afirmando que a ele compete, 'precipuamente, a guarda da Constituição' (art. 102, C.F.). Não há dúvidas de que a função de guardião da Constituição remete necessariamente ao caráter político que assume o Supremo Tribunal Federal no novo contexto constitucional. Afinal, a função de declarar o sentido e o alcance das regras jurídicas, especialmente na função jurisdicional de tutela da Constituição, traduz uma ação política ou, pelo menos, uma ação de inexorável repercussão política", op. cit., p. 62.
} 
judicialização das relações políticas e sociais $^{139}$. Por judicialização da política, esclarece BARROSO, não se deve entender ou confundir "com usurpação da esfera política por autoridades judiciais, mas traduz o fato de que muitas matérias controvertidas se inserem no âmbito de alcance da Constituição e podem ser convertidas em postulações de direitos subjetivos, em pretensões coletivas ou em processos objetivos" ${ }^{140}$. Ou seja, em razão da abrangência de matérias que a própria Constituição abarca, questões eminentemente políticas de outrora também se configuram como questões de direito e, portanto, passíveis de apreciação via jurisdição constitucional. Neste contexto, é importante notar que, dada a sensibilidade social de algumas dessas questões e das eventuais consequências políticas que elas podem ensejar, o Poder Legislativo tende a se abster de deliberar sobre as mesmas ou, simplesmente, é incapaz de gerar consensos mínimos acerca de tais matérias. Em razão disso, a ascensão do papel do Poder Judiciário e, em especial do Supremo Tribunal Federal, surge como uma decorrência praticamente inevitável e, mais precisamente, do ponto de vista políticojurídico, "como representante de decisões soberanas materializadas na Constituição Federal e difundidas por meio de um sentimento constitucional que, venturosamente, se irradiou pela sociedade como um todo"141.

Em síntese, no que concerne à legitimidade democrática, é razoável concluir que a jurisdição constitucional - e, portanto, o papel precípuo do Supremo Tribunal Federal no âmbito do desenho institucional brasileiro -, nas palavras de BINENBOJM, assenta-se como:

“[...] uma instância de poder contramajoritária, no sentido de que sua função é mesmo a de anular determinados atos votados e aprovados, majoritariamente, por

\footnotetext{
${ }^{139}$ BARROSO, Luís Roberto. Curso de Direito Constitucional Contemporâneo, op. cit., p. 512. Sobre este tema, especificamente, ver Luiz Werneck Vianna et al.. A Judicialização da Política e das Relações Sociais no Brasil. Rio de Janeiro: Revan, 1999.

${ }^{140}$ Ibid. p. 512.

${ }^{141}$ Ibid. p. 477. Ainda sobre esse aspecto: "É claro que uma corte constitucional poderia também, em linha de princípio, rever uma escolha que o legislador tenha feito, mas isso envolve naturalmente um ônus argumentativo muito mais elevado. Por tudo isso, o papel do Judiciário, quando não tenha havido deliberação política, é mais abrangente do que quando ela não tenha ocorrido. Se há lei, o STF só deve invalidá-la se a afronta à Constituição for inequívoca. Se não há lei, o Judiciário não pode deixar de decidir a questão alegando omissão normativa. Nesse caso, o seu poder se expande. Portanto, no fundo no fundo, quem tem o poder sobre o maior ou menor grau de judicialização é o Congresso: quando ele atua, ela diminui; e vice-versa”, ibid., p. 479.
} 
representantes eleitos. Nada obstante, entende-se, hodiernamente, que os princípios e direitos fundamentais, constitucionalmente assegurados, são, em verdade, condições estruturantes e essenciais ao bom funcionamento do próprio regime democrático; assim, quando a justiça constitucional anula leis ofensivas a tais princípios ou direitos, sua intervenção se dá a favor, e não contra a democracia. Esta a fonte maior de legitimidade da jurisdição constitucional."

Neste ínterim, constatada a legitimidade a priori da atuação jurisdicional, é de suma importância observar, para os fins a que se destinam o presente trabalho monográfico, que o pluralismo característico das sociedades contemporâneas e, em especial da conjuntura brasileira, deve ser o vetor norteador na construção social do próprio sentido e significado da Constituição no seio de qualquer constitucionalismo democrático. O Poder Judiciário, mas acima de tudo os Tribunais Constitucionais, sendo estes os intérpretes últimos da Constituição, não estão submetidos, em regra, a nenhum tipo de controle popular ou democrático a posteriori de suas decisões. Isto poderia representar certo déficit democrático da atuação da Corte, caso esta não se mostre permeável à sociedade. Como expõe brilhantemente o Ministro BARROSO, “o fato de a última palavra acerca da interpretação da Constituição ser do Judiciário não o transforma no único nem no principal - foro de debate e de reconhecimento da vontade constitucional a cada tempo. A jurisdição constitucional não deve suprimir nem oprimir a voz das ruas, o movimento social, os canais de expressão da sociedade. Nunca é demais lembrar que o poder emana do povo, não dos juízes" ${ }^{143}$. Desta forma, a noção habermesiana que rechaça a ideia de que o Tribunal Constitucional seria um intérprete mais qualificado, necessariamente, que qualquer outro núcleo social, mesmo não

\footnotetext{
142 BINENBOJM, Gustavo. Op. Cit., p. 282.

${ }^{143}$ BARROSO, Luís Roberto. Curso de Direito Constitucional Contemporâneo, op. cit., p. 448. Sob essa lógica, ressalta que em "grande medida, é essa a principal utilidade das audiências públicas, que têm sido conduzidas, com maior frequência, pelo STF. Os magistrados, assim como as pessoas em geral, não são seres desenraizados, imunes ao processo social de formação de opiniões individuais. O que não se poderia aceitar é a conversão do Judiciário em mais um canal da política majoritária, subserviente à opinião pública ou pautado pelas pressões da mídia. Ausente essa relação de subordinação, o alinhamento eventual com a vontade popular dominante é uma circunstância feliz e, em última instância, aumenta o capital político de que a Corte dispõe para poder se impor, de forma contramajoritária, nos momentos em que isso seja necessário”, ibid., p. 478.
} 
institucionalizado, é coerente com sua compreensão de democracia deliberativa e está em consonância com a sistemática da Constituição de 1988 de democracia participativa. Assim, a soberania popular impõe à jurisdição constitucional que, assevera BINENBOJM, embora à Corte Constitucional se cometa a palavra final sobre a interpretação da Constituição, suas decisões devem ser amplamente fundamentadas e expostas ao debate público, pois a crítica advinda da esfera pública possui um potencial racionalizador e legitimador. ${ }^{144}$

De fato, e sobretudo em se tratando de jurisdição constitucional em sede abstrata, com eficácia erga omnes, cujos efeitos se irradiam, via de regra, por uma infinidade de destinatários, afigura-se ainda mais conveniente uma abertura interpretativa que possa alcançar o maior espectro possível de interessados. Para tanto revela-se não somente apropriado, mas mesmo necessário, resgatar a ideia de uma sociedade aberta de intérpretes da Constituição, como formulado por Peter Häberle, segundo a qual o círculo de intérpretes da Lei Fundamental deve ser dilatado para abarcar não apenas as autoridades públicas e as partes formais nos processos de controle de constitucionalidade, mas todos os cidadãos e grupos sociais que, de uma forma ou de outra, vivenciam a realidade constitucional ${ }^{145}$. Assunto que será abordado e desenvolvido mais a fundo no capítulo subsequente.

\footnotetext{
${ }^{144}$ BINENBOJM, Gustavo. Op. Cit., p. 116 e HABERMAS, Jürgen. Soberania Popular como Procedimento, op. cit., p. 111.

${ }^{145}$ HÄBERLE, Peter. Hermenêutica Constitucional. A Sociedade Aberta dos Intérpretes da Constituição: contribuição para a interpretação pluralista e "procedimental" da Constituição. Tradução de Gilmar Ferreira Mendes. Porto Alegre: Sergio Antonio Fabris Editor, 1997, p. 15.
} 


\section{DA CONSTRUÇÃO DEMOCRÁTICA DO SENTIDO DA CONSTITUIÇÃO}

\subsection{A Sociedade Aberta dos Intérpretes da Constituição: a contribuição de Peter Häberle para a interpretação pluralista da Constituição}

O pressuposto, de cunho quase iluminista, de que os processos de tomadas de decisão política e de produção das normas jurídicas serão pautados principalmente pela razão ou, pelo menos, por um procedimento que se pretende racional, guarda algumas problematizações de ordem prática. Conforme já fora abordado, por confiar na racionalidade ínsita ao processo legislativo, em decorrência do seu modelo deliberativo extremamente dialético - e, portanto, autolegitimado -, HABERMAS reduz a importância da jurisdição constitucional à função de garantia das regras do jogo da deliberação pública, "através do monitoramento das premissas e formas da confecção das leis, cujo conteúdo deve ser deixado à decisão autônoma e consciente dos representantes de uma cidadania esclarecida". ${ }^{146}$ A estreita conexão, segundo CITTADINO, entre a plena autonomia do cidadão privada e pública - e a legitimidade do direito é o requisito intrínseco para que os cidadãos vejam a si próprios não apenas como destinatários, mas também como autores do seu direito, e assim reconhecendo-se como

\footnotetext{
${ }^{146}$ DOBROWOLSKI, Samantha Chantal. Op. Cit., p. 288. Realça a autora, neste sentido, que "[e]m virtude de sua concepção de democracia, para ser legítima, a jurisdição constitucional exercida no controle abstrato de normas tem que se limitar a proteger o sistema de direitos que possibilita a articulação entre a autonomia privada e pública dos cidadãos. Em consonância com sua leitura procedimentalista da Constituição, deve apostar no caráter intrinsecamente racional das condições procedimentais que apoiam a suposição de que o processo democrático, no seu todo, propicia resultados - e, pois, normas -, também racionais, oriundos da autodeterminação cidadã, não sendo, por isto, necessária nem justificável a intervenção corretiva e posterior de um terceiro, a desempenhar o 'papel de um regente que entra no lugar de um sucessor menor de idade'.", op. cit., p. 286.
} 
membros livres e iguais de uma comunidade jurídica ${ }^{147}$. Nesta linha, "o paradigma procedimental do direito pretende apenas assegurar as condições necessárias a partir das quais os membros de uma comunidade jurídica, através de práticas comunicativas de autodeterminação, interpretam e concretizam os ideais inscritos na Constituição" ${ }^{148}$. Esta estruturação teórica no pensamento habermesiano ajuda a compreender o motivo dessa atribuição "tímida" conferida à jurisdição constitucional, como ressalta DOBROWOLSKI:

\begin{abstract}
"As ideias de Habermas respondem a preocupações semelhantes às de Kelsen, cujo modelo de controle de constitucionalidade tem servido de referencial para os desdobramentos teóricos e práticos posteriores, inclusive em sentido oposto. Para ele, a jurisdição constitucional se coaduna com o regime democrático, por representar mecanismo de proteção às minorias perante as maiorias legislativas e seus possíveis abusos, além de evitar a concentração de poderes, com a divisão das funções e a atribuição a um órgão do Judiciário, terceiro imparcial entre administração e Legislativo, do controle de constitucionalidade das leis, restrito, não obstante, ao desempenho do papel de um legislador negativo, autocontido, que apenas realiza rigorosos juízos de compatibilidade lógica entre os enunciados normativos determinados - um constitucional e outro, de nível inferior -, sem qualquer referência a questões fáticas."149
\end{abstract}

Contudo, a dificuldade consiste quando se verifica, empiricamente, que nas sociedades contemporâneas - complexas, plurais e heterônomas - estas condições igualitárias e inclusivas que deveriam proporcionar o exercício da autonomia dos indivíduos, condições essenciais para o pressuposto racional do modelo deliberativo habermesiano, demonstra-se irreal, quando não utópico, se nos referirmos a países periféricos ou semiperiféricos, como o Brasil. Desta feita, o procedimento parlamentar, na prática, apresenta-se deficitário neste sentido, uma vez que não se mostra verdadeiramente suscetível à deliberação pública. Isto é facilmente constatado pela atual crise de representatividade, fenômeno sensível da contemporaneidade. Não obstante, se o pressuposto básico para a democracia é a garantia de um nível aceitável de existência e de acesso aos bens materiais e culturais, note-se que,

\footnotetext{
${ }^{147}$ CITTADINO, Gisele. Op. Cit., p. 209.

148 Ibid. p. 210.

${ }^{149}$ DOBROWOLSKI, Samantha Chantal. Op. Cit., p. 285.
} 
normalmente, isto é assegurado pelas prescrições constitucionais ao garantirem os direitos civis, políticos, econômicos, sociais, culturais e etc. Neste contexto, a jurisdição constitucional não deve atuar somente para amparar o processo político deliberativo, mas também a própria materialidade da Constituição. Vale dizer: "ao tribunal constitucional acaba sendo exigido um trabalho construtivo de concretização dos direitos que propiciam o exercício da autodeterminação cidadã, constitucionalmente afirmados". ${ }^{150}$

Dito isto, o reconhecimento da relevância da aplicação do direito, aqui abordado mediante a atividade jurisdicional, faz surgir novas indagações acerca da interpretação constitucional num cenário democrático. Sob este ângulo, HÄBERLE alerta que o estudo sobre a teoria da interpretação constitucional, tradicionalmente, concedeu substancial destaque aos objetivos e métodos do processo interpretativo, conferindo pouco significado à questão relativa aos participantes da interpretação ${ }^{151}$. Tal questão ganha especial realce se analisada sob o prisma das novas teorias da interpretação jurídica, que transferem a ênfase da norma para o intérprete a partir da superação da concepção clássica de que a atividade interpretativa constitui mera explicitação de um conteúdo intrínseco pré-existente do texto ou enunciado normativo. Neste sentido, Humberto Ávila realiza a distinção essencial entre texto e norma, compreendendo esta última como o sentido construído a partir da interpretação sistemática do primeiro. Salienta este autor que a

[...] matéria bruta utilizada pelo intérprete - o texto normativo ou dispositivo constitui uma mera possibilidade de Direito. A transformação dos textos normativos em normas jurídicas depende da construção de conteúdos de sentido pelo próprio intérprete. Esses conteúdos de sentidos, em razão do dever de fundamentação, precisam ser compreendidos por aqueles que os manipulam, até mesmo como condição para que possam ser compreendidos pelos seus destinatários. ${ }^{152}$

\footnotetext{
${ }^{150}$ Ibid. p. 290.

${ }^{151}$ HÄBERLE, Peter. Op. Cit., p. 11.

152 ÁVILA, Humberto. Teoria dos Princípios: da definição à aplicação dos princípios jurídicos. $14^{\mathrm{a}}$ ed. São Paulo: Malheiros, 2013, p. 28. Sobre isto, ressalta: "Essas considerações que apontam para a desvinculação entre o texto e seus sentidos também conduzem à conclusão de que a função da
} 
Sendo assim, a norma é construída - e não simplesmente revelada pelo intérprete. Segundo BARROSO, o pensamento jurídico clássico alimentava duas ficções: a) a de que o Direito era a expressão da razão, de uma justiça imanente; e b) a de que o Direito se realizava, se interpretava, se concretizava mediante uma operação lógica e dedutiva, em que o juiz fazia a subsunção dos fatos à norma, meramente pronunciando a consequência jurídica que nela se continha. ${ }^{153}$ A mudança de paradigma surge com a constatação da textura aberta de certas cláusulas gerais, como conceitos jurídicos indeterminados e princípios, por exemplo. A inerente ambiguidade da linguagem somada a positivação no texto constitucional - e, portanto, dotado de normatividade - de expressões com forte potencial de carga moral, gera situações em que o intérprete, invariavelmente, torna-se coparticipante do processo de criação do Direito, completando o trabalho do constituinte ou do legislador, ao integrar o sentido das cláusulas abertas através de suas próprias valorações. ${ }^{154}$ Isto posto, o enunciado normativo de textura aberta não contém integralmente os elementos de sua aplicação, mas tão somente sentidos mínimos que servirão de ponto de partida para o intérprete completálo por meio de um processo hermenêutico, e ao levar em conta as circunstâncias do caso concreto - se houver -, atribuindo-lhe significação.

Ciência do Direito não pode ser considerada como mera descrição do significado, quer na perspectiva da comunicação de uma informação ou conhecimento a respeito de um texto, quer naquela da intenção do seu autor", p. 34.

${ }^{153}$ BARROSO, Luís Roberto. Curso de Direito Constitucional Contemporâneo, op. cit., p. 345-346. 154 Ibid. p. 345. Sob esta lógica, Humberto Ávila, op. cit., p. 34: “De um lado, a compreensão do significado como conteúdo conceptual de um texto pressupõe a existência de um significado intrínseco que independa do uso ou da interpretação. Isso, porém, não ocorre, pois o significado não é algo incorporado ao conteúdo das palavras, mas algo que depende precisamente de seu uso e interpretação, como comprovam as modificações de sentidos dos termos no tempo e no espaço e as controvérsias doutrinárias a respeito de qual o sentido mais adequado que se deve atribuir a um texto legal. Por outro lado, a concepção que aproxima o significado da intenção do legislador pressupõe a existência de um autor determinado e de uma vontade unívoca fundadora do texto. Isso, no entanto, também não sucede, pois o processo legislativo qualifica-se justamente como processo complexo que não se submete a um autor individual, nem a uma vontade específica. Sendo assim, a interpretação não se caracteriza como um ato de descrição de um significado previamente dado, mas como um ato de decisão que constitui a significação e os sentidos de um texto. A questão nuclear disso tudo está no fato de que o intérprete não atribui 'o' significado correto aos termos legais. Ele tão só constrói exemplos de uso da linguagem ou versões de significado - sentidos -, já que a linguagem nunca é algo pré-dado, mas algo que se concretiza no uso ou, melhor, como uso". 
Diante disto, é preciso reconhecer o peso da interpretação constitucional, como meio para aplicação do Direito, no contexto pluralista e multicultural das sociedades contemporâneas, à medida em que se torna um instrumento de realização da democracia. Não obstante, salienta HÄBERLE que "a teoria da interpretação constitucional esteve muito vinculada a um modelo de interpretação de uma 'sociedade fechada'. Ela reduz, ainda, seu âmbito de investigação, na medida que se concentra, primariamente, na interpretação constitucional dos juízes e nos procedimentos formalizados" Desta forma, ante a constatação do caráter de criação - ou, recriação - do direito pela atividade hermenêutica, não se afigura democrático que esta atuação interpretativa fique restrita aos agentes formais da "sociedade jurídica”, ou seja, aos juízes, advogados, promotores, procuradores etc. A despeito da tecnicidade do direito reclamar uma interpretação estritamente jurídica e não política da Constituição, esta última se demonstra inevitável pelo próprio fenômeno linguístico, como já levantado, e também pelo próprio dinamismo que permeia o sentido da Constituição no tempo, adaptando-se a novas configurações sociais para não torna-se obsoleta. Além disso, o Direito, como área do conhecimento integrante das Ciências Humanas e Sociais não permanece estanque e blindado da interferência de outros ramos familiares como a própria Ciência Política, a Sociologia, a Antropologia ou a Filosofia, por exemplo. Esta interdisciplinaridade - ou multidisciplinariedade - apresentar-se crucial para a democratização da jurisdição constitucional no plano de uma sociedade extremamente pluralista. Sob esta ótica que HÄBERLE propõe uma sociedade aberta de intérpretes da Constituição ao sugerir a seguinte tese:

“[...] no processo de interpretação constitucional estão potencialmente vinculados todos os órgãos estatais, todas as potências públicas, todos os cidadãos e grupos, não sendo possível estabelecer-se um elenco cerrado ou fixado com numerus clausus de intérpretes da Constituição" 156

\footnotetext{
${ }^{155}$ HÄBERLE, Peter. Op. Cit., p. 12.

${ }^{156}$ Ibid. p. 13. Neste sentido ele afirma que "[u]ma análise genérica demonstra que existe um círculo muito amplo de participantes do processo de interpretação pluralista, processo este que se mostra muitas vezes difuso", p. 11.
} 
Sendo assim, a ideia da pulverização da interpretação constitucional visa justamente a extinguir, ou pelo menos mitigar, o monopólio dos atores formais "especializados" 157 ao adequar a jurisdição às exigências democráticas das sociedades pluralistas complexas. Para o eminente constitucionalista alemão, é impensável uma interpretação da Constituição sem o cidadão ativo e sem as potências públicas mencionadas pois quem vive a norma acaba por interpretá-la ou pelo menos por co-interpretá-la. Esclarecendo, "[t]odo aquele que vive no contexto regulado por uma norma e que vive com este contexto é, indireta ou, até mesmo diretamente, um intérprete dessa norma. O destinatário da norma é participante ativo, muito mais ativo do que se pode supor tradicionalmente, do processo hermenêutico. Como não são apenas os intérpretes jurídicos da Constituição que vivem a norma, não detêm eles o monopólio da interpretação da Constituição". 158 Tem-se, desta forma, uma democratização da interpretação constitucional, que, de acordo com DOBROWOLSKI,

[...] diante do desenho institucional da democracia contemporânea, que se deve adequar ao pluralismo e seus desdobramentos - multiculturalismo, demandas de direitos e de expansão da cidadania, lutas por reconhecimento e inclusão, necessidade de integração político-social mínima, num mundo racionalizado e em condições de pensamento pós-metafísico -, também o exercício da jurisdição constitucional deve abrir-se a estes influxos, passando a compreender mecanismos efetivos de participação dos cidadãos nos processos formais de construção do sentido da Constituição, que não deve ser descoberto nem revelado, mas racional e publicamente estabelecido, com a inserção e a consideração de todos os pontos de vista pertinentes, sobretudo dos que não detém suficiente representação política, não têm voz nem vez perante a maioria. Somente assim, é possível conferir uma maior medida de legitimidade política a esta atividade, tão necessária ao funcionamento da democracia, em sua faceta de regime político de poder limitado e em sua configuração societária aberta e pluralista, na qual, "dada a impossibilidade da revelação de valores éticos a priori, resta buscar a construção de procedimentos éticos de deliberação (g. o.)"159

\footnotetext{
${ }^{157}$ Nas palavras de Samantha Dobrowolski, propõe-se, "para tanto, uma interpretação constitucional aberta e pluralista que substitua o monopólio metodológico pela pluralidade metódica. Nesta linha de raciocínio, concebe o processo hermenêutico constitucional como instância crítica, sempre receptiva a novos questionamentos, aos valores pluralistas e inovações no curso do tempo, constituindo um sistema dinâmico", op. cit., p. 299.

${ }^{158}$ HÄBERLE, Peter. Op. Cit., p. 15.

${ }^{159}$ DOBROWOLSKI, Samantha Chantal. Op. Cit., p. 295-296.
} 
Cumpre ressaltar que mesmo do ponto de vista do conteúdo da Constituição, que estrutura não apenas o Estado, mas também a própria esfera pública, dispondo sobre a organização da própria sociedade e instituindo sistematicamente mecanismos de participação popular para fins de legitimação das tomadas de decisão, não podem os poderes constituídos sobretudo o Judiciário, como órgão garantidor último destes mecanismos tratar as forças sociais como meros objetos. Ao prever uma democracia de índole participativa a Constituição integra essas potências sociais e os cidadãos enquanto sujeitos ativos. ${ }^{160}$ Entendemos, inclusive, que esta lógica decorre sistematicamente da Constituição de 1988, por exemplo, sem que haja a necessidade de uma previsão expressa e específica em seu texto ou mediante determinação legal. Contudo, é plausível que se reconheça a pertinência de uma regulamentação no que concerne aos procedimentos por questões pragmáticas de viabilidade do próprio processo.

Aliás, sob uma perspectiva pragmática e realista, HÄBERLE antecipase às possíveis objeções e críticas que porventura viesse a sofrer, no sentido de que essa amplitude do círculo de intérpretes poderia "dissolver" a interpretação constitucional diante de um grande número de atores "não legitimados" formalmente - leia-se, legitimação mediante uma vinculação por um procedimento pré-estabelecido -, e que, consequentemente, acarretaria num risco ao postulado da unidade da Constituição. ${ }^{161} \mathrm{~A}$ respeito desta crítica, o autor ressalta que subsiste sempre a responsabilidade da jurisdição constitucional - e em última instância, do Tribunal Constitucional -, que fornece, em geral, a última palavra sobre a interpretação ${ }^{162}$. O que tão somente se propõe é uma abertura institucional à sociedade civil e núcleos sociais específicos no tocante aos temas que lhes sejam de interesse patente a fim de que tenham a oportunidade de contribuir para a construção do

\footnotetext{
${ }^{160}$ HÄBERLE, Peter. Op. Cit., p. 33.

${ }^{161}$ HÄBERLE, Peter. Op. Cit., p. 29.

162 Ibid. p. 14.
} 
sentido da Constituição. 163 Já no que se refere à "legitimação pelo procedimento", a mera previsão formal de participação no processo não significa, em si, aptidão para uma interpretação mais qualificada, nem mesmo do ponto de vista jurídico. Assim, sublinha HÄBERLE que "legitimação, que não há de ser entendida apenas em sentido formal, resulta da participação, isto é, da influência qualitativa e de conteúdo dos participantes sobre a própria decisão. Não se trata de um 'aprendizado' dos participantes, mas de um 'aprendizado' por parte dos Tribunais em face dos diversos participantes"164. Dito isto, é evidente que diante do pluralismo das sociedades complexas, a temática a ser discutida também direcionará, preferencialmente, os grupos e indivíduos participantes no processo. Vislumbra-se, desta forma, um sistema cooperativo em que essas "forças produtivas interpretadoras, que nitidamente atuam como pré-intérpretes, proporcionam materiais hermenêuticos - tais como os fatores e valores pluralistas que formam o espaço público, as possibilidades e necessidades existentes, todas as circunstâncias da situação e a contextualização temporal -, também para que, de outro lado, a partir destes influxos, os intérpretes em sentido estrito, os profissionais especializados e autorizados, voltem-se a compreender e aplicar a norma constitucional"165. Neste sentido, HÄBERLE ressalta que a

[...] ampliação do círculo de intérpretes aqui sustentada é apenas a consequência da necessidade, por todos defendida, de integração da realidade no processo de interpretação. É que os intérpretes em sentido amplo compõem essa realidade pluralista. Se se reconhece que a norma não é uma decisão prévia, simples e acabada, há de se indagar sobre os participantes no seu desenvolvimento funcional, sobre as forças ativas da law in public action (personalização, pluralização da interpretação constitucional!).

\footnotetext{
163 "Diante da objeção de que a unidade da Constituição se perderia com a adoção desse entendimento, deve-se observar que as regras básicas de interpretação remetem ao 'concerto' que resulta da conjugação desses diferentes intérpretes da Constituição no exercício de suas funções específicas. A própria abertura da Constituição demonstra que não apenas o constitucionalista participa desse processo de interpretação! A unidade da Constituição surge da conjugação do processo e das funções de diferentes intérpretes. Aqui devem ser desenvolvidas reflexões sob a perspectiva da Teoria da Constituição e da Teoria da Democracia”, ibid., p. 32-33.

${ }^{164}$ Ibid. p. 31-32.

${ }^{165}$ DOBROWOLSKI, Samantha Chantal. Op. Cit., p. 301.
} 
Qualquer intérprete é orientado pela teoria e pela práxis. Todavia, essa práxis não é, essencialmente, conformada pelos intérpretes oficiais da Constituição. ${ }^{166}$

Sendo, portanto, a interpretação constitucional uma atividade que, potencialmente, diz respeito a todos e fatalmente meio essencial de conformação mútua entre a Constituição e a realidade social, conclui assertivamente DOBROWOLSKI que os "elementos extraídos da visão participacionista de Häberle sobre a interpretação constitucional apresentamse como alternativa promissora, para conciliar os pressupostos racionalistas habermasianos e as exigências de legitimação decorrentes do pluralismo e das lutas multiculturais que reconfiguram a democracia na contemporaneidade" 167 . Como isso, o aparente paradoxo prático entre soberania popular e jurisdição constitucional pode ser "solucionado" a partir do entendimento de que uma sociedade é livre e aberta na medida que se amplia o círculo dos intérpretes da Constituição em sentido lato, permitindo que os cidadãos se vejam, simultaneamente, como autores e destinatários de seu próprio direito. Como salienta o próprio HÄBERLE, democracia desenvolve-se mediante a controvérsia sobre alternativas, sobre possibilidades e sobre necessidades da realidade e também o "concerto" científico sobre questões constitucionais, nas quais não pode haver interrupção e nas quais não existe e nem deve existir dirigente. ${ }^{168}$

\subsection{A influência de Häberle no contexto jurídico brasileiro: Leis 9.868/99 e 9.882/99}

Feitas estas concisas considerações a respeito da tese häberleana, não é difícil observar a sua compatibilidade teórica com a sistemática

\footnotetext{
${ }^{166}$ HÄBERLE, Peter. Op. Cit., p. 30-31.

${ }^{167}$ DOBROWOLSKI, Samantha Chantal. Op. Cit., p. 297.

${ }^{168}$ HÄBERLE, Peter. Op. Cit., p. 36.
} 
constitucional brasileira pós-1988. Como já fora explicitado no tópico 1.4 do presente trabalho, a Constituição de 1988 estabelece, de maneira estrutural, um aparato institucional que contempla amplamente a participação popular e a interação profícua entre Estado e sociedade. A nova jurisdição constitucional brasileira, inaugurada pela atual Carta Magna, não poderia ficar alheia desta lógica. Note-se, no que se refere ao controle de constitucionalidade pela via abstrata-concentrada, por exemplo, a considerável ampliação do rol de legitimados ativos para a propositura das ações diretas - ADI, ADC, ADCO e ADPF -, atividade outrora restrita ao Procurador-Geral da República. O art. 103 do texto corrente reserva a propositura da ação direta de inconstitucionalidade e da ação declaratória de constitucionalidade ao Presidente da República (inciso I); às Mesas do Senado Federal, da Câmara dos Deputados, das Assembleias Legislativas dos Estados e da Câmara Legislativa do Distrito Federal (incisos II, III e IV); ao Governador de Estado ou do Distrito Federal (V); ao Procurador-Geral da República (VI); ao Conselho Federal da OAB (VII); à qualquer partido político com representação no Congresso Nacional (VIII) e até mesmo às confederações sindicais ou entidades de classe de âmbito nacional (IX). Não obstante esta relevante ampliação, ela não atende substancialmente os anseios doutrinários de HÄBERLE, visto que ainda restringe os legitimados a um rol taxativo, ou seja, numerus clausus. Somando-se a isso, a Lei 9.868/99 que veio a regulamentar sobre o processo e julgamento da ADI e da ADC dispõe, no caput de seu art. $7^{\circ}$ que não se admitirá intervenção de terceiros no processo de ação direta de inconstitucionalidade. Sem embargo, o próprio $\S 2^{\circ}$ do mesmo dispositivo alude que

[o] relator, considerando a relevância da matéria e a representatividade dos postulantes, poderá, por despacho irrecorrível, admitir, observado o prazo fixado no parágrafo anterior, a manifestação de outros órgãos ou entidades.

Consiste, de maneira expressa, na admissão da figura do amicus curiae (do latim, "amigo da Corte") no processo de controle de constitucionalidade, ensejando a possibilidade de o Tribunal decidir as causas, segundo Gilmar Mendes, com pleno conhecimento de todas as suas implicações ou 
repercussões. Em razão disto, confere caráter pluralista e democrático (CRFB/88, art. $1^{\circ}$, Parágrafo Único) ao processo objetivo de controle abstrato de constitucionalidade. ${ }^{169}$ Trata-se portanto, nas palavras de BINENBOJM, de inovação bem inspirada na doutrina de HÄBERLE, que se insere no contexto de abertura da interpretação constitucional no país, permitindo que os indivíduos e grupos sociais participem ativamente das decisões do Supremo Tribunal Federal que afetem seus interesses. ${ }^{170}$ Cumpre ressaltar que, de acordo com a jurisprudência do próprio STF, a atuação dos amici curiae não está vinculada à fundamentação do autor ou mesmo submetida a uma suposta pretensão de "imparcialidade". Conforme ficou assentado por ocasião da ADIN n 3.045, rel. Celso de Mello, em virtude da causa petendi aberta, "por ensejar ampla indagação jurisdicional, por parte desta Suprema Corte, em torno dos possíveis fundamentos (invocados ou não) justificadores de eventual invalidade constitucional do ato normativo, permite, bem por isso, que 'amicus curiae' apoie a sua pretensão de inconstitucionalidade em fundamento jurídico diverso daquele invocado pelo autor do processo de fiscalização normativa abstrata, não se achando vinculado, portanto, aos argumentos utilizados pela parte principal" ${ }^{171}$. Ora, parece evidente que se o objetivo da norma é pluralizar o processo, deve-se não somente admitir mas incentivar a abertura para novos fundamentos diversos daqueles que ensejaram a propositura da própria ação, de modo a atingir o fim a que se propõe, qual seja: fornecer subsídios hermenêuticos dos mais variados e amplificados possíveis à Corte, de modo que sejam, concomitantemente, instrumentos de legitimação democrática da decisão a ser proferida.

Contudo, em que pese se reconheça a importância trazida pelo dispositivo, este não está imune a críticas, visto que, ao condicionar a participação do amicus curiae ao arbítrio exclusivo do relator, conferiu-lhe

\footnotetext{
${ }^{169}$ MENDES, Gilmar. Op. Cit., p. 1249.

170 BINENBOJM, Gustavo. Op. Cit., p. 162. Neste sentido, "nos processos de ação direta de inconstitucionalidade, o órgão ou entidade se habilitará para apresentar a sua visão da questão constitucional em testilha, oferecendo à Corte a sua interpretação, como partícipe ativo da sociedade aberta de intérpretes da Constituição", p. 163.

${ }^{171}$ Ibid. p. 163.
} 
caráter meramente facultativo, representando uma democratização bastante relativa. Sendo assim, ao estipular critérios amplos e indeterminados portanto, de textura aberta - como relevância da matéria em discussão e representatividade dos postulantes a amici curiae, certamente a inclusão dos potenciais afetados ou de minorias permanece dependendo da discricionariedade e da boa vontade dos julgadores. Em razão disso defende BINENBOJM que a

[...] previsão da irrecorribilidade da decisão do relator se aplica, por óbvio, àquelas decisões de conteúdo positivo, pois o dispositivo menciona expressamente apenas como "despacho irrecorrível" (rectius: trata-se de decisão interlocutória, e não de despacho) a decisão que admite a manifestação do amicus curiae. Por uma interpretação conforme à Constituição, que prestigie o direito ao contraditório e à ampla defesa, deve a Suprema Corte dar ao dispositivo a inteligência mais benéfica aos postulantes, permitindo-lhes que, por meio de agravo regimental, submetam a decisão indeferitória do relator ao Planário. ${ }^{172}$

Desta feita, se o propósito do art. $7^{\circ}, \S 2^{\circ}$ da Lei é o de pluralizar o debate constitucional - como de forma praticamente unânime a doutrina e a jurisprudência defendem -, mas o seu texto é tímido ou está aquém dessas pretensões almejadas, cabe ao intérprete integrar este sentido ao mencionado dispositivo ao "reinterpreta-lo" em consonância com a sistemática participativa da Constituição, sem, contudo, significar que com isso haja qualquer tipo de afronta à sua literalidade. É seguindo esta linha que também se defende a admissibilidade da sustentação oral pelos amici curiae, a despeito de ausência de previsão expressa, como mais uma das formas de concretização do sentido teleológico da norma. Destaca-se que o princípio da oralidade ganha substancial relevância nos tempos de hoje no âmbito da jurisdição constitucional concentrada, vez que a transmissão das sessões de julgamentos pela televisão - em especial pela TV Justiça - e a grande repercussão midiática que tomam os casos polêmicos e emblemáticos, configura-se parte do diálogo constitucional do Tribunal com a sociedade quando se permite a apresentação oral dos argumentos pelos amici curiae,

${ }^{172}$ Ibid. p. 165. 
tornando tal audiência mais um instrumento da sociedade aberta de intérpretes da Constituição. Assim, sustenta BINEMBOJM que o público, destinatário último da decisão, tem o direito de ser informado das posições e argumentos de todos os envolvidos na questão, não fazendo sentido "dar aos julgadores voz perante a opinião pública e limitar a participação do amicus curiae às peças escritas, que só serão conhecidas por aqueles que manusearam os autos do processo". ${ }^{173}$

Já no que concerne à Lei 9.882/99, que regula o procedimento da arguição de descumprimento de preceito fundamental (vulgo ADPF), notese que não há dispositivo explícito tratando da figura do amicus curiae. Contudo, salienta Pedro Lenza que o STF, excepcionalmente, vem admitindo a sua presença, aplicando, por analogia, o art. $7^{\circ}, \S 2^{\circ}$, da Lei 9.868/99, obviamente se observados os requisitos de relevância da matéria e a representatividade dos postulantes ${ }^{174}$. Entretanto, a própria Lei da ADPF traz, nos parágrafos do seu art. $6^{\circ}$, as respectivas redações:

Art. $6^{\circ} \ldots$

$\S 1^{\circ}$. Se entender necessário, poderá o relator ouvir as partes nos processos que ensejaram a arguição, requisitar informações adicionais, designar perito ou comissão de peritos para que emita parecer sobre a questão, ou ainda, fixar data para declarações, em audiência pública, de pessoas com experiência e autoridade na matéria.

$\S 2^{\circ}$. Poderão ser autorizadas, a critério do relator, sustentação oral e juntada de memoriais, por requerimento dos interessados no processo.

Vê-se que como tudo indica, como anota Gilmar Mendes, tal como na ação direta de inconstitucionalidade e na ação declaratória de constitucionalidade, a arguição de descumprimento de preceito fundamental deve assumir, igualmente, uma feição pluralista, com a participação de amicus curiae, que do mesmo modo poderá apresentar manifestação escrita como fazer sustentação oral. ${ }^{175}$

\footnotetext{
${ }^{173}$ Ibid. p. 167.

${ }^{174}$ LENZA, Pedro. Op. Cit., p. 334.

${ }^{175}$ MENDES, Gilmar. Op. Cit., p. 1314.
} 
Assim, realizadas estas breves observações quanto a suposta influência da obra de Peter Häberle no ordenamento jurídico brasileiro, em especial relativas aos instrumentos de realização constantes nas Leis 9.868/99 e 9.882/99, sob o intuito de uma democratização da jurisdição constitucional ao tentar ampliar o círculo de participantes no processo de interpretação constitucional, pode-se concluir que tais dispositivos legais trouxeram relevante contribuição para tal finalidade, porém ainda está longe de concretizar plenamente o que foi preconizado como uma verdadeira sociedade aberta de intérpretes da Constituição. Mostra-se, portanto, pertinente citar as interessantes sugestões trazidas por DOBROWOLSKI para darmos o próximo passo democrático sobre esta questão:

\begin{abstract}
"Nesta linha, a título ilustrativo e sem caráter exaustivo, podem ainda ser sugeridas outras hipóteses voltadas ao aprofundamento da democratização do controle de constitucionalidade no Brasil, a saber: ampliação do rol dos legitimados para propor ADIN's, incluindo-se o cidadão ('ADIN popular'); no âmbito do Ministério Público Federal, descentralização, através da atribuição de legitimação para agir nas ADIN's também a outros órgãos da Instituição (Procurador Federal dos Direitos do Cidadão e coordenadores de Câmaras de Coordenação e Revisão, por ex.), que, além do Procurador-Geral da República, possam atuar supletivamente, nas matérias de sua alçada (dentre as quais se destaca, por ex., a defesa dos direitos do cidadão e das comunidades indígenas); adoção obrigatória, e não facultativa, de audiências públicas e da inclusão de amicus curiae, quando apresentadas as solicitações respectivas; inclusão formal das minorias e grupos diferenciados nos processos sobre os interesses que lhes digam respeito em função de suas especificidades e diferenças, com a previsão de sua oitiva e o cuidado de se resguardar as linhas divergentes que possam existir no interior de cada comunidade minoritária ou movimento social, o que pode ser aquilatado a partir do caso concreto; superação das barreiras impostas pela interpretação atualmente conferida aos mecanismos e instrumentos jurídicoprocessuais existentes (como o critério da pertinência temática para a atuação dos legitimados do artigo 103 da $\mathrm{CF} / 88$ ), para o que uma regulamentação normativa clara e direta parece ser uma solução suficiente e hábil a resolver, processual e procedimentalmente, outras questões práticas relativas às sugestões anteriores. Acena-se ainda com a necessária revisão da arregimentação e indicação dos membros do STF, notadamente para se efetuar consultas públicas, sob a forma de listas apresentadas por entidades representativas dos operadores do sistema de justiça e organizações e associações da sociedade civil, em que são feitas as indicações do corpo social para posterior avaliação dos poderes Legislativo e Executivo, já encarregados da escolha final - que mantém o equilíbrio e o caráter democrático (representativo) da jurisdição constitucional. Ademais devem ser fixados mandatos para o exercício dos juízes na Corte, a fim de se garantir a necessária rotatividade e oxigenação, tributárias da abertura postulada pelo Estado democrático de direito, em que também o lugar do poder de dizer o direito deve permanecer 'vazio' e inocupável de uma vez para sempre" 176
\end{abstract}

${ }^{176}$ DOBROWOLSKI, Samantha Chantal. Op. Cit., p. 308. 


\section{CONCLUSÃO}

Dado o exposto ao longo do presente trabalho monográfico, cabe realizar algumas sucintas conclusões e suceder com eventuais sugestões e propostas. Como apresentado, os fatores que representam a legitimidade da atuação dos órgãos do Estado nas sociedades contemporâneas, sob o prisma de uma teoria da democracia mais consentânea às aspirações dos tempos atuais, devem estar em eterna busca de concretização da soberania popular através de instrumentos cada vez mais ampliados e sofisticados de participação da sociedade civil, de modo que tal participação tenha por escopo o abrandamento das tensões provocadas pela desconexão entre a vontade popular - sem que esta seja compreendida como homogênea, unânime ou unívoca - e as decisões e políticas institucionais, fenômeno típico da complexidade social que permeia a contemporaneidade e que gera as principais incongruências na relação verticalizada Estado-sociedade.

Ora, se a premissa essencial das atuais democracias reside na palavrachave pluralismo, resta evidente que continuar apostando num modelo puramente, ou ao menos excessivamente, representativo, soa tão absurdo e está tão fadado ao fracasso quanto descartá-lo completamente. O mistério consiste justamente em encontrar a medida de equilíbrio entre a viabilidade prática e objetiva das tomadas de decisão num contexto político dinâmico e, simultaneamente, a garantia de que os indivíduos sejam e sintam-se (co)autores, e não somente destinatários, de tais prestações estatais, conferindo-lhes portanto a devida legitimidade democrática. Não obstante a tensão inerente entre Poder Constituinte e poderes constituídos, ainda que o primeiro seja manifestação genuína da vontade popular, assevera-se que, diante do pluralismo e complexidade das sociedades pós-modernas, a instituição de uma ordem jurídica é imprescindível para a possibilidade da própria democracia no que concerne à sua organização. Neste sentido, a paradoxal relação entre Direito e Democracia se dá exatamente por esse 
tensionamento mútuo ao mesmo tempo em que também se pressupõem reciprocamente.

Sob esta ótica, revela-se interessante o modelo elaborado por Jürgen Habermas de uma democracia deliberativa-procedimental que preconiza uma "razão comunicativa" fruto de uma profunda e constante interação dialética dos indivíduos entre si e entre os indivíduos e as instituições no âmbito de uma esfera pública, que só pode assegurada por uma ordem jurídica. Assim, o Direito tem a função precípua de garantir direitos humanos e fundamentais que são o pressuposto básico para o exercício regular dessa deliberação eminentemente democrática e que, por sua vez, conferirá ares de legitimidade ao próprio direito através do procedimento. Foi visto, também, que o modelo habermasiano está em perfeita consonância com a sistemática constitucional brasileira pós-1988, que está assentada sobre verdadeiros pilares de uma democracia tipicamente participativa, instituindo diversos meios de participação do cidadão, foros de debates institucionalizados e espaços públicos próprios à manifestação popular. Neste ínterim, a Carta Política serve como efetivo garante jurídico de direitos fundamentais essenciais ao exercício da democracia, consolidando na realidade brasileira um real constitucionalismo democrático.

Sendo assim, a partir do reconhecimento do conteúdo programático e da força normativa da Constituição, torna-se imperiosa a reflexão acerca do relevante papel da jurisdição constitucional no plano desse constitucionalismo democrático como problematização, e mesmo relativização, do próprio princípio majoritário, historicamente ínsito ao conceito tradicional de democracia. Para tanto, resguardar certa categoria de direitos independentemente da vontade de maiorias, eventuais ou não, do sistema representativo se mostra pré-condição de uma democracia verdadeiramente plural e tolerante, que reconhece o valor de sua própria heterogeneidade, que não subjuga grupos culturalmente oprimidos e minoritários frente à constante tendência de homogeneizar a sociedade de 
acordo as visões sociais hegemônicas. É neste contexto que se sobressalta a importância de um mecanismo de controle de constitucionalidade das leis e dos atos do Poder Público e, portanto, o protagonismo da jurisdição constitucional como decorrência da centralidade político-jurídica da própria Constituição. A indagação natural surge então da própria legitimidade democrática dessa jurisdição, vez que, a superação da velha crença kelseniana de atuação dos Tribunais Constitucionais como meros "legisladores negativos" mostrou que também estes órgãos, ao aplicar a Constituição e outros textos jurídicos, são criadores do Direito mediante a atividade hermenêutica, sob o prisma das mais vanguardistas teorias da interpretação jurídica.

Dito isto, se a norma jurídica é construída pelo intérprete, cumpre questionar quem são (ou devem ser) estes intérpretes. Nesta medida apresenta-se a importante contribuição de Peter Häberle com sua tese da sociedade aberta de intérpretes da Constituição, ao sugerir um sistema pluralista e, portanto, mais democrático, de interpretação constitucional. Esta configuração apetece às pretensões democráticas da contemporaneidade ao pluralizar o debate em todas as esferas, institucionais ou não, e permitir uma construção democrática do sentido da própria Constituição, harmonizando o postulado da soberania popular com os mecanismos da jurisdição constitucional. Neste sentido, Samantha Chantal Dobrowolski salienta:

\begin{abstract}
"Os instrumentos de participação cidadã devem ser implementados em todos os setores da vida pública, além de dependerem de uma sociedade civil organizada e mobilizada. Contudo, ainda que esta não exista ou não atue adequadamente, devem ser adotados, na democracia, procedimentos institucionalizados para fomentar a comunicação permanente e recíproca entre todas as partes implicadas em determinado âmbito de decisão, tanto na esfera administrativa quanto judicial, através da conformação do chamado status activus processualis" $" 177$
\end{abstract}

\footnotetext{
${ }^{177}$ DOBROWOLSKI, Samantha Chantal. Op. Cit., p. 306. Nesta linha, ressalta ao citar o próprio Häberle, que "[a] democracia pluralista produz uma consequência organizatória da dignidade humana [...] - o que aparece como simples 'forma estatal', é uma correspondência mais profunda. $\mathrm{O}$ ser humano dotado de dignidade própria desde o nascimento cresce graças a processos culturais de socialização em um status de liberdade, que lhe atribui a participação democrática, o status de 'homo politicus' como 'natural'. Dignidade humana e democracia compõem as duas caras da mesma res publica, que cunham o Estado constitucional do atual estágio de evolução".
} 
Portanto, o estabelecimento de um novo paradigma participativo, em especial em matéria de jurisdição constitucional, ao desmonopolizar a interpretação constitucional afigura-se concretizar a ideia de uma construção democrática e pluralista do significado da Constituição, instituída que foi sob a égide da soberania popular, deve também ser moldada e aplicada no tempo pela mesma potência criadora. 


\section{BIBLIOGRAFIA}

ÁVILA, Humberto. Teoria dos Princípios: da definição à aplicação dos princípios jurídicos. 14ª ed. São Paulo: Malheiros, 2013.

BARROSO, Luís Roberto. Curso de Direito Constitucional Contemporâneo. Os Conceitos Fundamentais e a Construção do Novo Modelo. $5^{\mathrm{a}}$ ed. São Paulo: Saraiva, 2015.

O Controle de Constitucionalidade no Direito Brasileiro. $6^{\mathrm{a}}$ ed.

São Paulo: Saraiva, 2012.

BINENBOJM, Gustavo. A Nova Jurisdição Constitucional Brasileira. Legitimidade democrática e Instrumentos de realização. $4^{\mathrm{a}}$ ed. Rio de Janeiro: Renovar, 2014.

BOBBIO, Norberto. Estado, Governo, Sociedade: para uma teoria geral da política. Tradução de Marco Aurélio Nogueira. São Paulo: Paz e Terra, 2012. O Futuro da Democracia. Tradução de Marco Aurélio Nogueira. $2^{\mathrm{a}}$ ed. São Paulo: Paz e Terra, 2011.

CANOTILHO, J. J. Gomes. Direito Constitucional e Teoria da Constituição. $7^{\mathrm{a}}$ ed. Coimbra: Almedina, 2003.

CARDOSO, Rodrigo Mendes. Iniciativa Popular Legislativa da Assembleia Nacional Constituinte ao Regime da Constituição de 1988: um balanço. Rio de Janeiro. 2010. Dissertação (Mestrado) - Departamento de Direito da PUCRio.

CITTADINO, Gisele. Pluralismo, Direito e Justiça Distributiva: elementos da filosofia constitucional contemporânea. $4^{\mathrm{a}}$ ed. Rio de Janeiro: Lumen Juris, 2009. 
DOBROWOLSKI, Samantha Chantal. A Construção Social do Sentido da Constituição na Democracia Contemporânea: entre soberania popular e direitos humanos. Rio de Janeiro: Lumen Juris, 2007.

GUIMARAENS, Francisco de. O Poder Constituinte na Perspectiva de Antonio Negri: um conceito muito além da modernidade hegemônica. Rio de Janeiro. 2002. Dissertação (Mestrado) - Departamento de Direito da PUCRio.

HÄBERLE, Peter. Hermenêutica Constitucional. A Sociedade Aberta dos Intérpretes da Constituição: contribuição para a interpretação pluralista e "procedimental” da Constituição. Tradução de Gilmar Ferreira Mendes. Porto Alegre: Sergio Antonio Fabris Editor, 1997.

HABERMAS, Jürgen. Direito e Democracia: entre facticidade e validade. Tradução de Flávio Beno Siebeneichler. Rio de Janeiro: Tempo Brasileiro, 1997, vol. 1.

Soberania Popular como Procedimento: um conceito normativo de espaço público. Tradução de Márcio Suzuki. Novos Estudos CEBRAP, nº 26, 1990, pp. 100-113.

HESSE, Konrad. A Força Normativa da Constituição. Tradução de Gilmar Ferreira Mendes. Porto Alegre: Sergio Antonio Fabris Editor, 1991.

HOLSTON, James. Cidadania Insurgente: disjunções da democracia e da modernidade no Brasil. Tradução de Claudio Carina; revisão técnica de Luísa Valentini. São Paulo: Companhia das Letras, 2013.

KELSEN, Hans. A Garantia Jurisdicional da Constituição, in Jurisdição Constitucional. 13 a ed. São Paulo: WMF Martins Fontes, 2013, pp. 119-209. Quem deve ser o guardião da Constituição?, in Jurisdição Constitucional. 13ª ed. São Paulo: WMF Martins Fontes, 2013, pp. 237-298. LENZA, Pedro. Direito Constitucional Esquematizado. 16 ${ }^{\mathrm{a}}$ ed. São Paulo: Saraiva, 2012. 
MEIRELLES, Hely Lopes et al. Mandado de Segurança e Ações Constitucionais. 36 a ed. São Paulo: Malheiros, 2014.

MENDES, Gilmar Ferreira; BRANCO, Paulo Gustavo Gonet. Curso de Direito Constitucional. $7^{\mathrm{a}}$ ed. São Paulo: Saraiva, 2012.

MÜLlER, Friedrich. Quem é o Povo? A Questão Fundamental da Democracia. Tradução de Peter Naumann; revisão de Paulo Bonavides. Editora Max Limonad, 1998.

NEGRI, Antonio. O Poder Constituinte: ensaio sobre as alternativas da modernidade. Tradução de Adriano Pilatti. $2^{a}$ ed. Rio de Janeiro: Lamparina, 2015 .

O’DONNEL, Guillermo. Uma outra Institucionalização: América Latina e alhures. Lua Nova no 37, 1996, pp. 5-31.

ROUSSEAU, Jean-Jacques. $O$ Contrato Social. Tradução de Paulo Neves. Porto Alegre: L\&PM Pocket, 2009.

SANTOS, Boaventura de Sousa et al. Democratizar a Democracia: os caminhos da democracia participativa. Rio de Janeiro: Civilização Brasileira, 2002.

. Para uma Revolução Democrática da Justiça. $3^{\mathrm{a}}$ ed. São Paulo:

Cortez, 2011.

SILVA, José Afonso da. Curso de Direito Constitucional Positivo. $35^{\mathrm{a}}$ ed. São Paulo: Malheiros, 2012.

Poder Constituinte e Poder Popular: estudos sobre a Constituição. $1^{\text {a }}$ ed. São Paulo: Malheiros, 2002.

THOREAU, Henry David. A Desobediência Civil \& outros escritos. Tradução de Alex Marins. São Paulo: Martin Claret, 2001.

VIANNA, Luiz Werneck et al. A Judicialização da Política e das Relações Sociais no Brasil. Rio de Janeiro: Revan, 1999. 